\title{
Schwann Cells and Deleted in Colorectal Carcinoma Direct Regenerating Motor Axons Towards Their Original Path
}

\author{
Allison F. Rosenberg, - Jesse Isaacman-Beck, Clara Franzini-Armstrong, and Michael Granato \\ Department of Cell and Developmental Biology, University of Pennsylvania Perelman School of Medicine, Philadelphia, Pennsylvania 19104-6058
}

\begin{abstract}
After complete nerve transection, a major challenge for regenerating peripheral axons is to traverse the injury site and navigate toward their original trajectory. Denervated Schwann cells distal to the lesion site secrete factors promoting axonal growth and serve as an axonal substrate, yet whether Schwann cells also actively direct axons toward their original trajectory is unclear. Using live-cell imaging in zebrafish, we visualize for the first time how in response to nerve transection distal Schwann cells change morphology as axons fragment, and how Schwann cell morphology reverses once regenerating growth cones have crossed the injury site and have grown along distal Schwann cells outlining the original nerve path. In mutants lacking Schwann cells, regenerating growth cones extend at rates comparable with wild type yet frequently fail to cross the injury site and instead stray along aberrant trajectories. Providing growth-permissive yet Schwann cell-less scaffolds across the injury site was insufficient to direct regenerating growth cones toward the original path, providing compelling evidence that denervated Schwann cells actively direct regenerating axons across the injury site toward their original trajectory. To identify signals that guide regenerating axons in vivo, we examined mutants lacking the deleted in colorectal carcinoma (DCC) guidance receptor. In these $d c c$ mutants, a significant fraction of regenerating motor axons extended along aberrant trajectories, similar to what we observe in mutants lacking Schwann cells. Thus, Schwann cell and $d c c$-mediated guidance are critical early during regeneration to direct growth cones across the transection gap and onto their original axonal trajectory.
\end{abstract}

Key words: DCC; peripheral nerve; regeneration; Schwann cell; zebrafish

\section{Introduction}

In the peripheral nervous system, injured axons regenerate, although many aspects of this process, including how regenerating axons navigate across the lesion site toward their original synaptic targets, are not well understood. The regenerative capacity of peripheral axons varies with the severity and the type of injury (Zochodne, 2008; Brushart, 2011; Zochodne, 2012). For example, after a crush injury, glial-derived basal lamina remains intact, providing regenerating axons with a permissive substrate across the injury site (Cajal, 1928; Scherer and Easter, 1984; Nguyen et al., 2002). In contrast, complete nerve transection results in a Schwann cell and basal lamina free gap, presenting a major hurdle for regenerating axons. In rodents, removing the distal nerve stump or increasing the injury gap beyond $12 \mathrm{~mm}$ dramatically reduces regeneration, consistent with the idea that the distal nerve provides axons with critical signals for navigation across

\footnotetext{
Received May 15, 2014; revised Aug. 27, 2014; accepted Sept. 21, 2014

Author contributions: A.F.R. and M.G. designed research; A.F.R. and C.F.-A. performed research; A.F.R., J.I.-B., and C.F.-A. analyzed data; A.F.R. and M.G. wrote the paper.

This work was supported by National Institutes of Health Grants T32-GM007229 and F31-NS071722 (A.F.R.) and R01 EY024861, R21-NS-070032, and HD-37975 (M.G.) and Muscular Dystrophy Association Grant 131174 (M.G.). We thank laboratory members for technical advice and critical comments, B. Appel, S. Kucenas, W. Talbot, T. Piotrowski, and D. Raible for providing zebrafish lines and reagents, and M. Lush for the sox10:Gal4 line. We also thank the laboratory members of J. Raper, B. Appel, and W. Talbot for reagents and technical advice.

The authors declare no competing interests.

Correspondence should be addressed to Michael Granato at: granatom@mail.med.upenn.edu.

DOI:10.1523/JNEUROSCI.2007-14.2014

Copyright $\odot 2014$ the authors $\quad 0270-6474 / 14 / 3414668-14 \$ 15.00 / 0$
}

the gap, toward the distal nerve stump, and onto their original trajectory (Lundborg et al., 1981, 1982, 1986).

After injury, regenerating axons interact with a variety of nonneuronal cells, including macrophages, fibroblasts, perineural ensheathing glia, and Schwann cells (Beuche and Friede, 1984; Perry et al., 1987; Stoll et al., 1989; Martini et al., 1990; Perry and Brown, 1992; Schröder et al., 1993; Abernethy et al., 1994; Weis et al., 1994; Parrinello et al., 2010; for review, see Brosius Lutz and Barres, 2014), yet if and to what extent these cell types direct regenerating axons toward their original developmental path has not been determined in vivo. Schwann cells in particular are thought to be essential for regeneration. Denervated Schwann cells in the distal nerve stump, known as the bands of Bungner (Bungner, 1891), serve as a substrate for regenerating axons and provide diffusible factors, including NGF, BDNF, and FGF, to promote axonal outgrowth (Lundborg et al., 1986; Ide, 1996; Chen et al., 2007). However, whether Schwann cells also provide directional information to regenerating axons pioneering the injury gap is unclear.

Here we take advantage of the genetic tractability and transparency of larval zebrafish to investigate how regenerating motor axons cross an injury-induced transection gap and select their original trajectory in live, intact animals. Using in vivo microscopy, we compared the dynamic behavior of regenerating axons and Schwann cells in wild-type larvae to mutants lacking all Schwann cells. Remarkably, the absence of Schwann cells did not impede growth cone sprouting or axonal growth, as regenerating axons extended over considerable distances. However, axons 
lacked directionality and traveled along ectopic trajectories. Providing Schwann cell-less axonal scaffolds across the injury site and along the original trajectory was insufficient to fully restore directionality to regenerating axons, suggesting that Schwann cells produce factors that direct regenerating axons to their appropriate trajectory. Finally, in mutants lacking the axonal guidance receptor deleted in colorectal carcinoma $(d c c)$, regenerating axons strayed from their original path onto ectopic trajectories, reminiscent of the phenotype observed in mutants lacking Schwann cells. We conclude that Schwann cells and dccdependent signaling direct regenerating axons toward their original developmental trajectories in vivo.

\section{Materials and Methods}

Zebrafish genetics and transgenes. All transgenic lines were maintained in the Tuebingen or TLF genetic background and raised as described previously (Mullins et al., 1994). The $\operatorname{Tg}(m n x 1: G F P)^{m l 2}$ (Flanagan-Steet et al., 2005) and the $\operatorname{Tg}(X l a . T u b b: D s R e d)^{z f 148}$ (Peri and Nüsslein-Volhard, 2008) lines were used to label spinal motor nerves. The $\mathrm{Tg}(\operatorname{sox} 10(7.2)$ : $m r f p)^{\text {vu234 }}$ (Kucenas et al., 2008), $\mathrm{Tg}$ (sox10:nlseos) ${ }^{\text {w18 }}$ (Prendergast et al.,

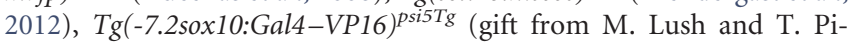
otrowski, University of Utah, Salt Lake City, UT), and $\mathrm{Tg}$ (UAS:GFP) (Asakawa et al., 2008) lines were used to label Schwann cells, and the Tg(T2KUAS-E1b:nfsB-mCherry) ${ }^{\text {jh17 }}$ (Parsons et al., 2009) line was used to conditionally ablate Schwann cells. The $T g\left(m n x 1: W l d^{s}-G F P\right)^{p 152}$ line

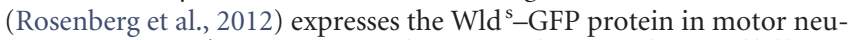
rons. The sox $10^{-1-} /$ colorless $(c l s)^{m 241}$, erbb2 $^{s t 50}, \operatorname{erbb}^{\text {st48 }}, \mathrm{dcc}^{2 m 130198}$, and $n r g 1^{z 26}$ (Kelsh et al., 1996; Dutton et al., 2001; Lyons et al., 2005; Jao et al., 2008; Perlin et al., 2011) mutants were used. Male and female zebrafish were used, and all zebrafish work was conducted in accordance with Institutional Animal Care and Use Committee regulatory standards.

Stochastic cell labeling. Axons were stochastically labeled by microinjection of $33 \mathrm{pg} m n x 1: D s R e d$ DNA at the one-cell stage as described previously (Thermes et al., 2002). The Discosoma red (DsRed) fluorophore is strongly expressed by $24 \mathrm{~h}$ after fertilization, concomitantly with the expression of GFP in the transgenic line $T g(m n x 1: G F P)^{m l 2}$.

Genotyping. Genotyping protocols for the following mutants were performed as described previously: $d c c^{z m 130198}$ (Jain et al., 2014); erbb2 $2^{\text {st5o }}$ and erbb3 $^{\text {st48 }}$ (Lyons et al., 2005); and $n r g 1^{z 26}$ (Perlin et al., 2011).

Whole-mount fluorescent in situ hybridization and immunohistochemistry. Antisense digoxigenin-labeled $d c c$, net1a (Net4.6 probe), and net $1 b$ RNA probes were used for in situ hybridization performed as described previously (Lakhina et al., 2012). In situ signals were amplified using a cyanine 5-coupled tyramide system (TSA Plus Cyanine 5 System; PerkinElmer Life and Analytical Sciences; product number NEL745001KT). In situ hybridization was followed by immunohistochemistry using rabbit anti-GFP (1:400; Life Technologies) and goat anti-rabbit Alexa Fluor 488-conjugated secondary antibody (1:500; Invitrogen) to visualize motor neurons. Processed larvae were mounted laterally in Vectashield (Vector Laboratories) and imaged in $1 \mu \mathrm{m} \mathrm{sec-}$ tions with a $20 \times$ water lens and a $40 \times$ water-immersion lens on a Zeiss 710 confocal laser scanning microscope (LSM 710) using ZEN2010 software.

The anti-sox 10 antibody was a generous gift from S. Kucenas (University of Virginia, Charlottesville, VA). Five-day-old zebrafish larvae were fixed in $4 \%$ PFA with $0.1 \%$ Triton X-100 for $3 \mathrm{~h}$ and then washed one time for 5 min successively with PBS with $1 \%$ Triton X-100 (PBStx), deionized water with $1 \%$ Triton X-100, and $100 \%$ acetone, followed by $100 \%$ cold acetone for $10 \mathrm{~min}$ at $-20^{\circ} \mathrm{C}$. Then larvae were washed three times for 5 min in PBStx, blocked in 5\% goat serum/PBStx, and incubated in $5 \%$ goat serum/PBStx $/ 1^{\circ}$ antibody for $1 \mathrm{~h}$ at room temperature and then $4^{\circ} \mathrm{C}$ overnight. Larvae were washed extensively with PBStx and incubated with goat anti-rabbit Alexa Fluor 594-conjugated secondary antibody (1:500; Invitrogen). Larvae were mounted in Vectashield (Vector Laboratories), and images were acquired with an Olympus IX81 equipped with a Yokogawa CSU 10 scan head combined with a Hamamatsu EMCCD camera (model C9100-13); acquisition and hardware were controlled by Slidebook version 5.0.
Fluorescent $m$ RNA quantification. In FIJI, fluorescent double-labeled 6 $\mu \mathrm{m}$ stacks for mRNA and motor neuron-GFP were made into a series of maximum projection images and then processed to subtract background, and a mean filter of 1 pixel was applied. A region of interest (ROI) was drawn around the ventral spinal cord in which motor neurons were labeled with GFP. mRNA levels within the ROI were counted in two ways: (1) by counting the number of local maxima; and (2) by measuring overall fluorescence levels. This analysis was repeated in smaller ROIs drawn around individual GFP-positive cell bodies.

Nerve transection and live imaging. Nerve transection and live imaging were performed as described previously (Rosenberg et al., 2012).

Axon growth extent quantification. Axon growth extent was quantified $48 \mathrm{~h}$ post-transection (hpt) using a rubric of three semiquantitative categories, illustrated in Figure $1 N-P$. Transected nerves in which axons failed to regrow or did not extend through the entire length of the ventral myotome are categorized as "no/weak regeneration." Nerves with at least one fascicle that extended through the entire length of the ventral myotome are categorized as "moderate regeneration." Finally, nerves with two or more fascicles extending through the entire length of the ventral myotome are categorized as "strong regeneration."

Axon misguidance quantification. Misguided axons were identified at $48 \mathrm{hpt}$ as axons above the lateral line that regrew in areas that were not populated by axons in pre-lesion images.

Axon growth rate, Schwann cell migration, and proliferation quantification. Regenerating nerves and Schwann cells were imaged approximately every $10 \mathrm{~min}$ from $\sim 6$ to $\sim 13 \mathrm{hpt}$, as described previously (Rosenberg et al., 2012). In NIH ImageJ, the scale was set on these movies to 0.192 $\mu \mathrm{m} /$ pixel and pixel distance and aspect ratio to 1.0. Growth was measured at each hour by drawing lines over newly grown axon segments and recording the length in micrometers per hour. Schwann cell distance was measured using the same method, measuring from the top of the distal stump to the leading edge of the Schwann cell nucleus at each time point. Numbers of migrating and proliferating Schwann cells were counted.

Electron microscopy. Nerves were transected as described previously in $5 \mathrm{~d}$ post-fertilization ( $\mathrm{dpf}$ ) larvae, and then larvae were removed from agarose and incubated in $\mathrm{E} 3$ at $28^{\circ} \mathrm{C}$ until fixation at 6 or $48 \mathrm{hpt}$, following previous methods (Rosenberg et al., 2012). Longitudinal coronal sections through the tail segment extending for several myotomes on either side of the transected regions were cut starting from the ventral side and progressing dorsally. When the notochord was reached, a group of thin sections was cut at intervals of $\sim 12-15 \mu \mathrm{m}$ to view cross-sections of the nerve distal and up to the damaged sites. Cross-sectional profiles of nerves were present immediately adjacent to the notochord midway along each sarcomere. Profiles on the uninjured left side of the same animals were used as control undamaged nerves.

Image processing. Image stacks were compressed into maximum intensity projections (MIPs) in Slidebook version 5.0. MIPs were exported and gamma adjusted to 0.5 in NIH ImageJ for increased visibility using a custom macro called "Gamma Adjustment Batch: 0.5 ," color assigned by acquisition wavelength, and merged using a custom macro called "Batch RG Merge," modified from a macro called "Batch RGB Merge." Both macros were deposited in the online NIH ImageJ macro collection and can be downloaded at http://rsb.info.nih.gov/ij/macros/. Brightness, contrast, and color levels were adjusted for maximal visibility in Adobe Photoshop CS4.

Schwann cell ablation. Schwann cells were ablated using $\operatorname{Tg}(-7.2 s 0 \times 10$ : Gal4-VP16;T2KUAS-E1b:nfsB-mCherry) larvae by bath applying $8 \mathrm{~mm}$ metronidazole (Mtz) in E3 at $3.5 \mathrm{dpf}$ and refreshing the solution daily, similar to what has been described previously (Curado et al., 2007; Parsons et al., 2009). Ablation was confirmed by the absence of mCherrypositive sox10 cells and the presence of mCherry-positive debris throughout the animal at $5 \mathrm{dpf}$. After transection at $5 \mathrm{dpf}$, larvae were maintained in $5 \mathrm{~mm}$ Mtz.

Statistical analysis. Fisher's exact $t$ tests were performed on all applicable datasets. 

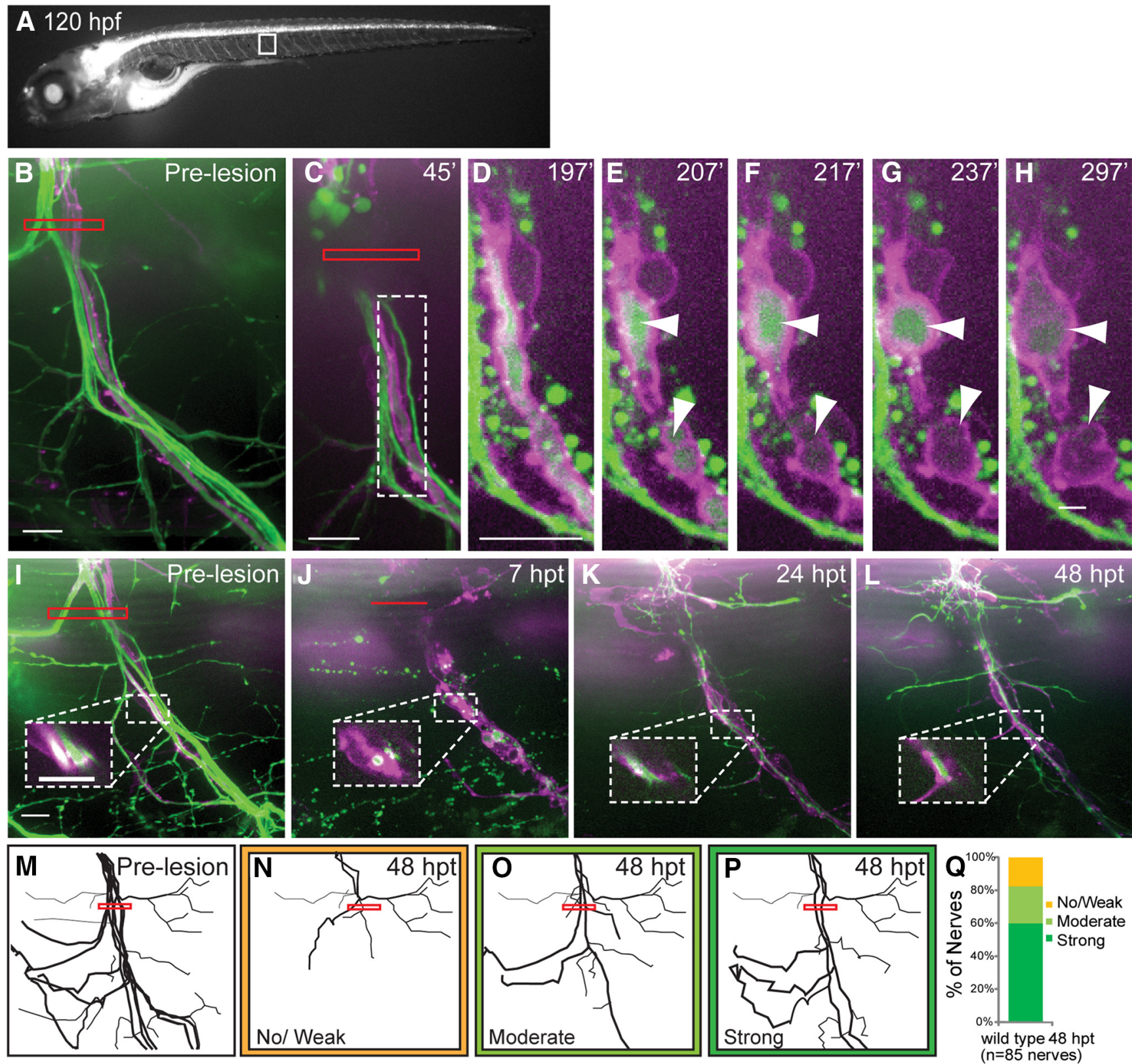

Figure 1. Schwann cells change morphology as transected motor nerves degenerate and regenerate. $A, A t 5 \mathrm{dpf}, \operatorname{Tg}(\mathrm{mnx}$ 1:GFP) larva expresses GFP in spinal motor neurons and axons. White box, Single motor nerve. $\boldsymbol{B}-\boldsymbol{H}$, Schwann cells change morphology as axons fragment. $\boldsymbol{B}, \boldsymbol{I}$, Pre-lesion nerve in $5 \mathrm{dpf} T g$ (mnx1:GFP;sox10 - $m R$ RFP) larva. Red box, Area of laser axotomy. As axons fragment, Schwann cell membranes (magenta) surrounding axons (green) change morphology $(\boldsymbol{C}-\boldsymbol{H})$ and in $2 \mathrm{~h}$ begin degrading axonal debris contained within their membranes $(\boldsymbol{D}-\boldsymbol{H})$ (arrowheads, $\boldsymbol{E}-\boldsymbol{H})$. $I-L$, Schwann cell membrane morphology changes over $48 \mathrm{hpt}$ (insets, $1 \mu \mathrm{m} z$-plane). J, At $7 \mathrm{hpt}$, distal axons have completely fragmented, and remaining denervated Schwann cell membranes appear gnarled. $\boldsymbol{K}$, At $24 \mathrm{hpt}$, axons have regrown into the ventral myotome along original trajectory in which Schwann cells remained. $\boldsymbol{L}$, At 48 hpt after axon regeneration, Schwann cell membranes appear thinner and smoother, like pre-lesion Schwann cells. Scale bar, $10 \mu \mathrm{m}$. $\boldsymbol{M}-\boldsymbol{P}$, Diagram regeneration categories for quantification of nerve regeneration at $48 \mathrm{hpt}(\mathbf{Q})$.

\section{Results}

Live-cell imaging after nerve injury reveals orchestrated cellular dynamics of axons and Schwann cells

Changes in Schwann cell morphology are a hallmark of nerve degeneration, yet the in vivo dynamics of this process have not been observed. Therefore, we fully transected individual nerves in larvae aged $5 \mathrm{dpf}$ and then documented changes in Schwann cell morphology using time-lapse microscopy (Fig. 1A). Ventrally projecting zebrafish motor nerves consist of $\sim 60-80$ motor axons, and individual axons form branches that synapse with muscle fibers and myotendinous junctions along hemisegment boundaries (Fig. 1 A, B; Myers, 1985; Myers et al., 1986; Wester- field et al., 1986; Zhang et al., 2004; Rosenberg et al., 2012). At 5 dpf, large-diameter axons are wrapped by approximately three to five layers of myelin, approximately equivalent to that in mouse and rat during the first postnatal week (Peters and Muir, 1959; Schlaepfer and Myers, 1973; Hahn et al., 1987; Garbay et al., 2000). Motor nerves were laser transected as reported previously (Rosenberg et al., 2012) within the first $\sim 20 \mu \mathrm{m}$ of the peripheral nerve trajectory in larvae expressing GFP in motor neurons and RFP in Schwann cells $T g(m n x 1: G F P$;sox10:mRFP). Before axon fragmentation, Schwann cell membranes were elongated and closely associated with motor axons (Fig. 1B,C). Once axons started to fragment, Schwann cell membranes distal to the lesion 
site began to reorganize, changing from a tube-like morphology to a shorter, more rounded morphology containing large blebs of fluorescently labeled axonal debris (Fig. $1 D-H$ ). The fluorescent intensity of the encircled debris decreased over the next $2 \mathrm{~h}$ (Fig. $1 E-H)$, consistent with the observation that axonal debris is degraded by phagocytic vesicles present in Schwann cells (Holtzman and Novikoff, 1965; Scherer and Easter, 1984).

To visualize changes in Schwann cell morphology as axons regenerate, we transected nerves and imaged Schwann cells and regenerating motor axons over a $48 \mathrm{~h}$ time period (Fig. $1 I-L$ ). By $7 \mathrm{hpt}$, the nerve segment distal to the transection site had fragmented, leaving behind only axonal debris and a ribbon of denervated distal Schwann cells, known as the band of Bungner (Fig. 1J; Bungner, 1891). Compared with pre-lesion Schwann cell membranes (Fig. 1I), these distal Schwann cell membranes appeared distended and gnarled (Fig. $1 E-H$ ). Within $24 \mathrm{hpt}$, motor neurons reextended axons past the lesion site, in close proximity to the original path delineated by denervated Schwann cells (Fig. $1 \mathrm{~K})$. By $48 \mathrm{hpt}$, regenerating axons had traversed the ventral myotome in which they reestablished complex branches. Concomitantly, Schwann cell membranes reverted to their thinner appearance in proximity to regenerating axons (Fig. $1 I-L$ ), and their membranes reacquired a smoother, pre-lesion like morphology (Fig. 1I). Single micrometer $z$-planes (Fig. $1 I-L$, insets) demonstrate that axons extended in close proximity to the denervated distal Schwann cells, similar to what has been shown in mammalian systems (Scherer and Easter, 1984; Westerfield et al., 1986; Chen et al., 2007; Zochodne, 2008; Rosenberg et al., 2012). To quantify the extent of axon regeneration at $48 \mathrm{hpt}$, we applied a three-category rubric illustrated in Figure $1 M-Q$ (for details, see Materials and Methods). In wild-type larvae, $\sim 80 \%$ of transected motor nerves ( $n=85$ nerves from 22 larvae) regrew successfully through the length of the ventral myotome (Fig. 1Q, "strong" and "moderate" categories) and formed functional synapses (Rosenberg et al., 2012). Thus, laser axotomy triggers changes in axonal and Schwann cell morphology, and live imaging reveals that these changes are highly coordinated between the two cell types, during both degeneration and regeneration.

\section{Schwann cell migration and proliferation during the early phase of axon regeneration}

We next asked how individual Schwann cells respond to nerve transection. Previous studies have shown that Schwann cell migration and proliferation are critical to axon regeneration because blocking these processes leads to misrouted axons (Cajal, 1928; Politis et al., 1982; Hall, 1986a; Stoll et al., 1989; Chen et al., 2005). To visualize Schwann cell behaviors, we used larvae in which motor axons are labeled with DsRed via the $T g(X l a . T u b b$ : DsRed) transgene (Peri and Nüsslein-Volhard, 2008) and Schwann cell nuclei with the photoconvertable fluorophore Eos via the $T g$ (sox10:nlseos) transgene (Prendergast et al., 2012). Using an anti-sox10 antibody, we first confirmed that the sox10: nlseos line faithfully labels all Schwann cell nuclei on ventral motor nerves (Fig. $2 H-J ; n=348$ of 351 nuclei colabeled).

We then transected and imaged motor nerves every $10 \mathrm{~min}$ from $\sim 6$ to $\sim 13 \mathrm{hpt}$, a period during which motor axons are actively regrowing (Fig. $2 A-F$; see Fig. $6 A-H$ ). Live-cell imaging revealed that sox 10 -positive cells migrated in $\sim 42 \%$ of transected nerves ( $n=27$ migrating cells on 19 nerves of 45 nerves analyzed; Fig. $2 G$ ). Migration on the distal nerve stump toward the transection site was more frequent ( $n=24$ migrating cells on 19 nerves) than migration on the proximal nerve stump toward the transection site ( $n=3$ migrating cells on 19 nerves), suggesting that
Schwann cells respond differently to nerve transection based on their relative position to the injury site. Finally, we observed dividing Schwann cells in only $14 \%$ of transected nerves $(n=6$ Schwann cells on 45 nerves). Given that $\sim 80 \%$ of transected nerves regenerate successfully (Fig. 1Q), our data suggest that Schwann cell migration and proliferation are likely less important for the initial stages of axon regeneration when axons cross the lesion site and extend toward their original trajectory.

\section{Motor axon regeneration is impaired in the absence of Schwann cells}

To define the in vivo role of Schwann cells for axonal regeneration, we examined four genetic mutant strains lacking differentiated Schwann cells. Specifically, we analyzed mutants lacking the sox10 transcription factor, which is critical for early neural crest development, mutants lacking erbb2 or erbb3, which form a heterodimeric receptor critical for Schwann cell differentiation, and mutants lacking the ErbB2/ErbB3 ligand nrg1typeIII (Kelsh et al., 1996; Dutton et al., 2001; Lyons et al., 2005; Perlin et al., 2011). In all mutants, motor axons develop without delay, and through 5 dpf, their motor axons are morphologically indistinguishable from those in wild-type siblings (Fig. $3 A$, E; data not shown). Furthermore, the absence of Schwann cells did not affect Wallerian degeneration and debris removal (Rosenberg et al., 2012).

Compared with wild-type siblings, axon regeneration was severely affected in all mutants lacking Schwann cells (Fig. 3C,D compared with $G, H$ ), consistent with what has been reported for lateral line nerve regeneration (Villegas et al., 2012). Quantification of axon regeneration at $48 \mathrm{hpt}$ revealed that, in mutants lacking Schwann cells, in $50-80 \%$ of transected nerves, the regenerating axons failed to extend along their original trajectory through the ventral myotome compared with $<20 \%$ in wild-type siblings (Fig. 3I). Instead, regenerating axons grew extensively into lateral territories, in which they formed thick fascicles through the lateral myotome in areas that are sparsely innervated both before lesion and after regeneration in the presence of Schwann cells (Fig. $3 G, H$ ), suggesting that Schwann cells direct regenerating axons.

We next wanted to determine the degree of regeneration at the ultrastructural level. For this, we performed electron microscopy at $6 \mathrm{hpt}$ when most axons have fragmented and at $48 \mathrm{hpt}$ when axons have regenerated (Rosenberg et al., 2012). Compared with uninjured nerves, which contain Schwann cells adjacent to axonal profiles separated by myelin sheets (Fig. $4 A, B$ ), axotomized nerves at $6 \mathrm{hpt}$ appeared disorganized at the level of the transection site, lacking discernible axonal membranes and instead containing collapsed myelin sheets (Fig. 4C). Similar to intact control nerves (Fig. 4D,E), transected nerves at $48 \mathrm{hpt}$ contained Schwann cells adjacent to both small- and large-diameter axons, which had regrown past the lesion site onto their original path (Fig. $4 F$ ). At this time point, myelin levels had not yet returned to pre-lesion levels, with only partially formed myelin sheets detectable (Fig. $4 F$ compared to Fig. $4 E$ ). To understand how axons regrow in the absence of Schwann cells, we examined nerves in sox $10^{-1-}$ mutants. Except for the lack of Schwann cells, axonal profiles and the nerve environment appeared normally organized in uninjured nerves (Fig. 4G,H). However, after injury in sox $10^{-/-}$mutants, axonal profiles at $48 \mathrm{hpt}$ were observed invading aberrantly into muscle territories, deviating far from the normal motor nerve path (Fig. 4I), consistent with the misguided regrowth observed using confocal microscopy (Fig. $3 G, H$ ). 

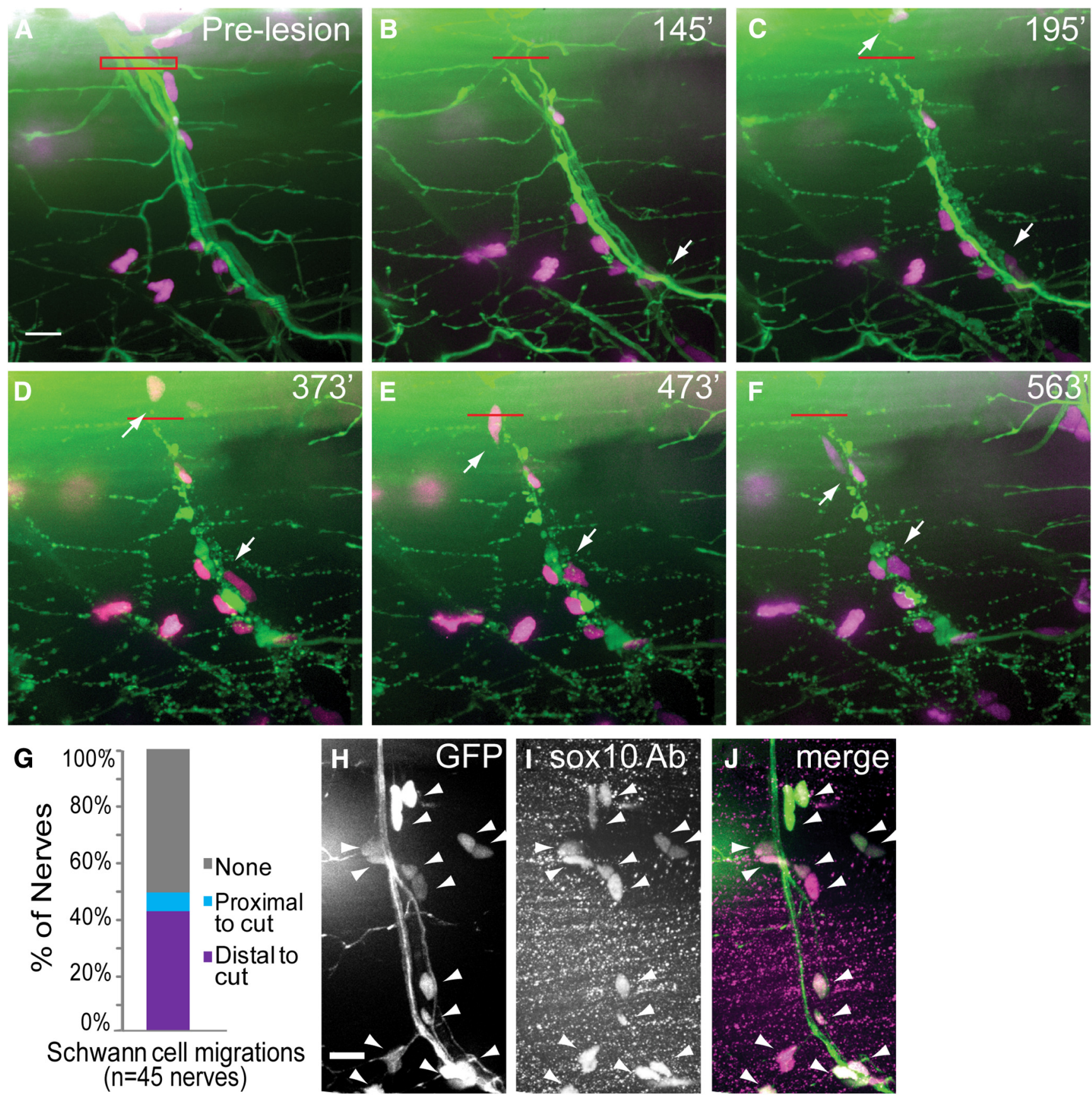

Figure 2. Schwann cells migrate after transection. $\boldsymbol{A}$, Pre-lesion nerve in $5 \mathrm{dpf} T$ (sox10:nlseos;:Xla.Tubb:DsRed) larva. Red box, Area of laser axotomy. $\boldsymbol{B}-\boldsymbol{F}$, Schwann cells labeled with nuclear GFP (pseudocolored magenta) migrate from distal and proximal locations toward the transection gap (arrows, leading edge of the nucleus). The proximal Sox10-expressing cell crosses the transection gap $(\boldsymbol{E}, \boldsymbol{F}) . \mathbf{G}$, Quantification of Schwann cell nuclear migration. $\boldsymbol{H}-\boldsymbol{J}$, Schwann cells labeled in the transgenic Tg(sox10:nlseos;mnx1-GFP) line are Sox 10 positive. $\boldsymbol{H}$, GFP labels the motor nerve and Schwann cell nuclei. I, Sox10 antibody (Ab) labels all Sox10-expressing nuclei along the motor nerve.J, Merge of GFP (green) and Sox10 antibody staining (magenta; $n=346$ nuclei colocalize, 2 are only GFP positive and 5 only Sox10 antibody positive). Scale bar, $10 \mu \mathrm{m}$.

Schwann cells direct the growth of regenerating axons toward the original nerve path

One possible mechanism by which Schwann cells might direct regenerating axons is through extracellular marks produced by Schwann cells during development. To exclude this possibility, we ablated Schwann cells acutely, just before nerve transection. Schwann cells were ablated by treating larvae expressing the enzyme nitroreductase under the sox 10 promoter in $T g(-7.2$ sox 10 : Gal4-VP16;T2KUAS-E1b:nfsB-mCherry (abbreviated as sox10: NTR-mCherry; Curado et al., 2007; Parsons et al., 2009). In control larvae (sox10:NTR-mCherry positive; Mtz negative and
sox10:NTR-mCherry negative; Mtz positive), transected motor nerves regenerated indistinguishably from those in wild type (Fig. $5 A-D$, quantified in $G$ ). In contrast, beginning Mtz exposure of sox10:NTR-mCherry-positive larvae at $3.5 \mathrm{dpf}$ efficiently ablated sox10:NTR-mCherry-positive cells by $5 \mathrm{dpf}$ (data not shown). Importantly, by $48 \mathrm{hpt}$, regenerating axons had extended along the same aberrant trajectories we observed in sox $10^{-/-}$mutants lacking Schwann cells (Fig. $5 F, G$ ). This suggests that the presence and activity of Schwann cells before nerve transection does not influence axon regeneration after injury and strongly suggests that Schwann cells must be present during regeneration to direct regrowing axons. 

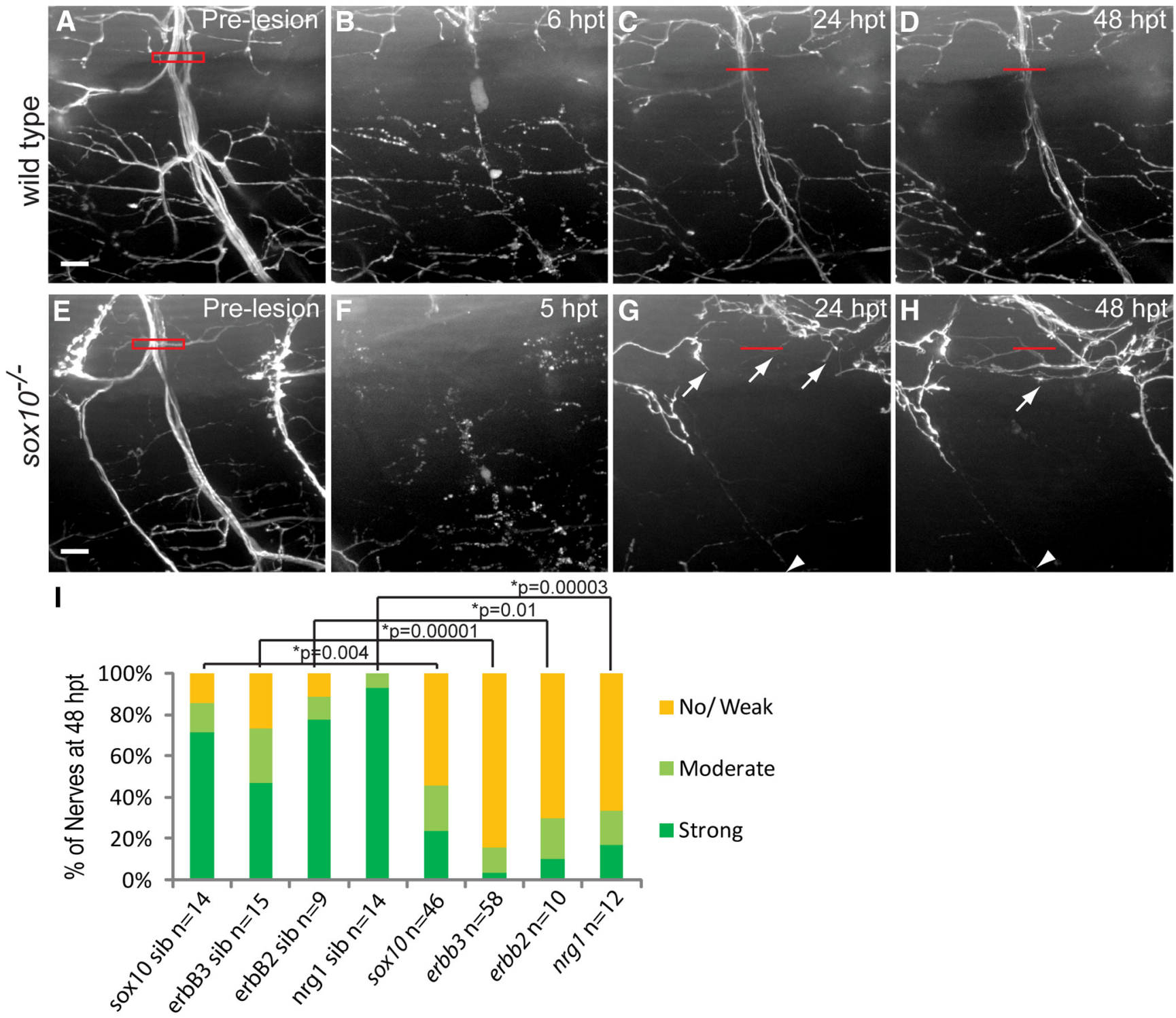

Figure 3. In the absence of Schwann cells, regenerating axons extend along ectopic trajectories. $\boldsymbol{A}-\boldsymbol{D}$, Axon regeneration in wild-type animals. $\boldsymbol{A}$, Pre-lesion nerve in wild-type sibling $\mathrm{Tg}(\mathrm{mnx1}$ :GFP). $\boldsymbol{B}, \mathrm{By} \sim 6 \mathrm{hpt}$, axons have completely fragmented. C, D, At $24 \mathrm{hpt}$ and through $48 \mathrm{hpt}$, axons regrew into the ventral myotome, along the full extent of the original path, and branched. $\boldsymbol{E}-\boldsymbol{H}$, Axon regrowth is misguided after transection in larvae lacking Schwann cells. $\boldsymbol{E}, \operatorname{In}$ a $\operatorname{Tg}(\mathrm{mnx} 1: G F P) ;$ sox $10^{-1-}$ mutant, axons appear normal before lesion. $\boldsymbol{F}$, At $5 \mathrm{hpt}$, nerve fragmentation and debris removal appear normal. $\mathbf{G}, \boldsymbol{H}$, Axons sprout and extend from the proximal stump yet fail to grow along the original, central myotomal path and do not reinnervate the ventral half of the ventral myotome (arrows, most ventral regrowth; arrowheads, regrowth along hemisegment boundary). Red box, Area of laser axotomy. Scale bar, $10 \mu \mathrm{m} . I$, Quantification of the extent of nerve regrowth at $48 \mathrm{hpt}$ using categories established in Figure 1 in siblings (sib) and mutants that lack Schwann cells (sox $10^{-/-}$, erbB3 ${ }^{-/-}$, erbB2 ${ }^{-/-}$, and nrgltypellI $^{-/-}$).

We next asked when axons begin to depend on Schwann cells. For this, we transected motor nerves in siblings and sox $10^{-/-}$ mutants during the time period when motor axons are still pioneering through the myotome ( $1 \mathrm{dpf})$, at $2 \mathrm{dpf}$ when additional axons extend along the pioneering tracts, and at 3 and $4 \mathrm{dpf}$ when axons have fully extended through the myotome. In wild-type animals, nerves were able to fully regenerate, independent of when the nerves were transected (Fig. $5 H$ ). In contrast, there was a marked shift in the regenerative capacity of $\operatorname{sox} 10^{-1-}$ mutants. Although nerves transected at $1 \mathrm{dpf}$ regenerated equally as well as wild-type nerves (Fig. $5 \mathrm{H}$ ), nerves transected at $2-4 \mathrm{dpf}$ resulted in the same aberrant growth of regenerating axons observed in sox $10^{-/-}$mutant nerves transected at $5 \mathrm{dpf}$ (Fig. $5 \mathrm{H}$ ). Thus, the capacity for motor axons to regrow along their original path rapidly shifts from a Schwann cell-independent mechanism, present only during the phase of initial outgrowth, to a life-long Schwann cell-dependent mechanism that has already begun during development.

Finally, we asked whether Schwann cells influence growth rates and/or growth direction when regrowing axons cross the injury gap and extend toward their original trajectory. Timelapse analyses of regenerating wild-type axons revealed that regeneration commences as early as $3-5 \mathrm{hpt}$, when multiple growth cones sprouted from the proximal stump in all directions (data not shown). Beginning at $\sim 5-7 \mathrm{hpt}$, growth cones had crossed the injury gap (Fig. $6 A-C$ ), and then over the next few hours rapidly pioneered a path along their original trajectory (Fig. $6 C-E$ ). Additional regenerating axons joined and formed fascicles with the pioneer axons, and over the next 10 hours, these fascicles extended through the entire length of the ventral myotome (Fig. $6 E-H$ ).

Analysis of $\operatorname{sox} 10^{-/-}$mutants revealed that regenerative growth cones sprouted and extended from the proximal stump in 


\section{6 hpt control}
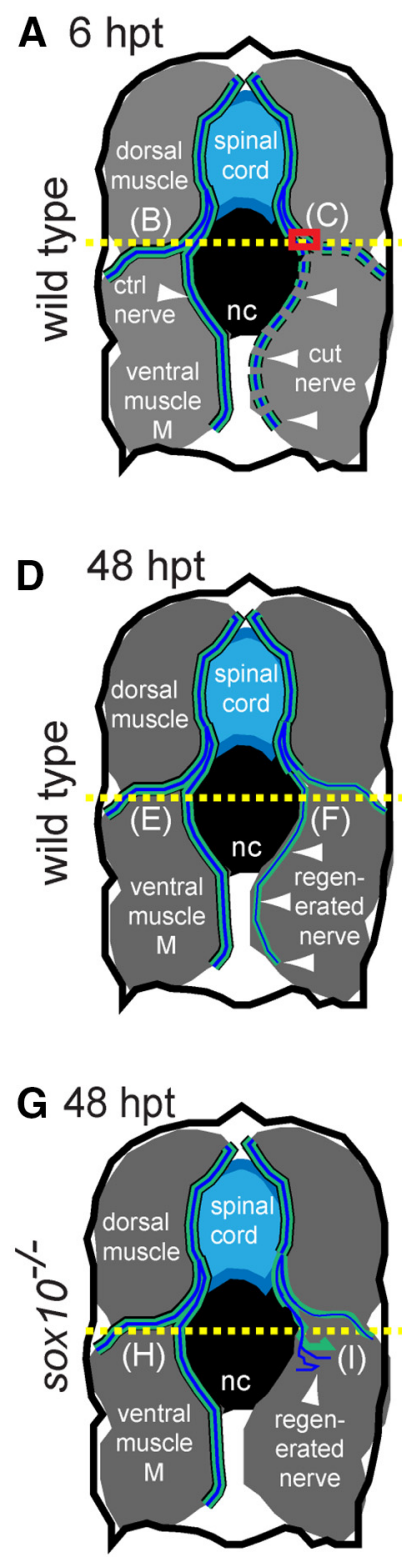

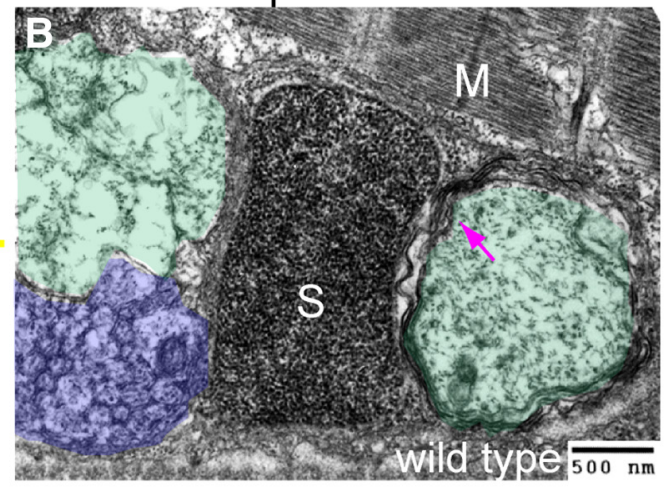

48 hpt control

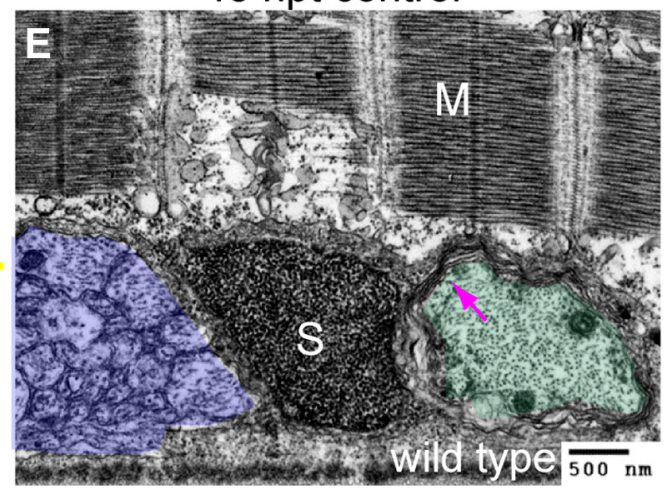

48 hpt control

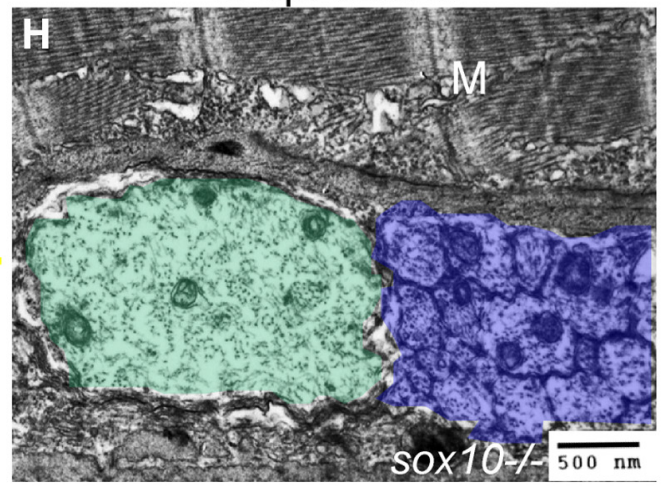

6 hpt transected
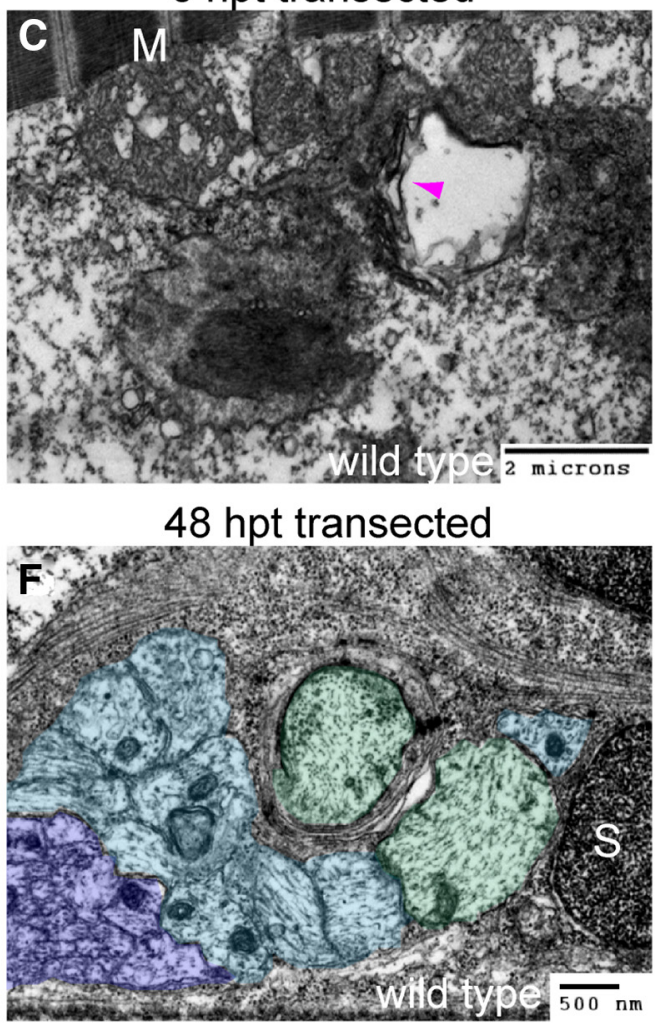

$48 \mathrm{hpt}$ transected

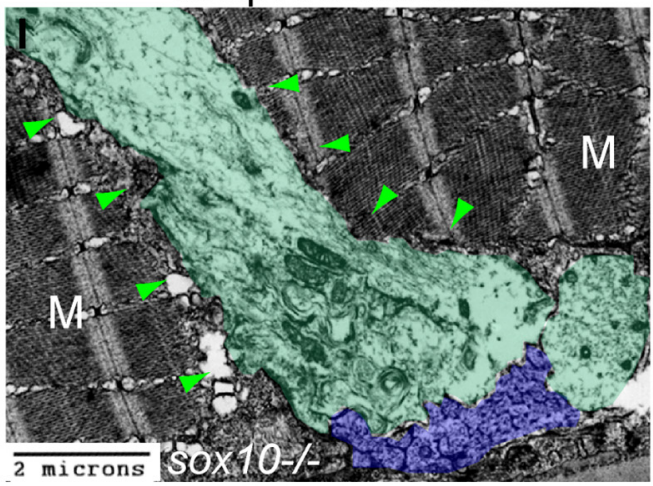

Figure 4. Ultrastructural sections of degenerating and regenerating motor nerves. $A, D, G$, Diagrams approximately indicate positions of nerve slices for electron micrographs from control uncut nerves $(\boldsymbol{B}, \boldsymbol{E}, \boldsymbol{H})$, transected nerves $(\boldsymbol{C}, \boldsymbol{F}, \boldsymbol{I})$ at $6 \mathrm{hpt} \mathrm{in} \mathrm{wild} \mathrm{type}(\boldsymbol{B}, \boldsymbol{C})$, at $48 \mathrm{hpt} \mathrm{in} \mathrm{wild} \mathrm{type}(\boldsymbol{E}, \boldsymbol{F})$, and at $48 \mathrm{hpt} \mathrm{in} \mathrm{sox} 10^{-1-}(\boldsymbol{H}, \boldsymbol{I})$. Magenta arrows, Myelin; magenta arrowheads, collapsed myelin membranes; green shading, large-diameter axons; teal shading, medium-diameter axons; blue shading, small-diameter axons; blue arrowheads, possible axon blebs; green arrowheads, misguided axons; $S$, Schwann cell; $M$, muscle; $n c$, notochord.

multiple directions, indistinguishable from those in wild type (Fig. 6I-P;n $=16$ nerves). However, in contrast to wild type, growth cones in sox $10^{-1-}$ mutants continued to extend in all directions, without establishing a growth preference toward their original path (Fig. $6 I-P)$. Furthermore, axons that initially grew in the appropriate ventral direction rarely extended ventrally beyond the level of the lateral line and instead grew along ectopic lateral trajectories (Fig. $6 L-P$ ). Importantly, average forward growth rates and maximum forward growth rates of axons in mutants and siblings were similar (wild type, $0.22 \mathrm{~mm} / \mathrm{d}$ average with a maximum rate of $0.50 \mathrm{~mm} / \mathrm{d}, n=8$ axons from 8 nerves in 6 animals; sox $10^{-/-}$mutants, $0.23 \mathrm{~mm} / \mathrm{d}$ average rate with a maximum rate of $0.44 \mathrm{~mm} / \mathrm{d}, n=10$ axons from 9 nerves in $6 \mathrm{mu}$ tants). Thus, in the absence of Schwann cells, regenerating axons retain the capacity to sprout growth cones and extend, but they stray onto multiple, aberrant trajectories, failing to stabilize toward their original developmental path. Combined, these genetic analyses provide compelling evidence that, within a few hours after axons sprout from the nerve stump, Schwann cells provide regenerating growth cones with guidance critical for axons to navigate toward the original path.

\section{Axonal scaffolds fail to compensate for Schwann} cell-dependent guidance

Our data are consistent with the idea that, as growth cones sprout from the proximal nerve stump, Schwann cells direct regrowing axons onto their original path. Conceptually, this could be accomplished through several mechanisms. The prevailing view in the literature suggests that denervated Schwann cells and their surrounding basement membrane act as a substrate, sufficient to 

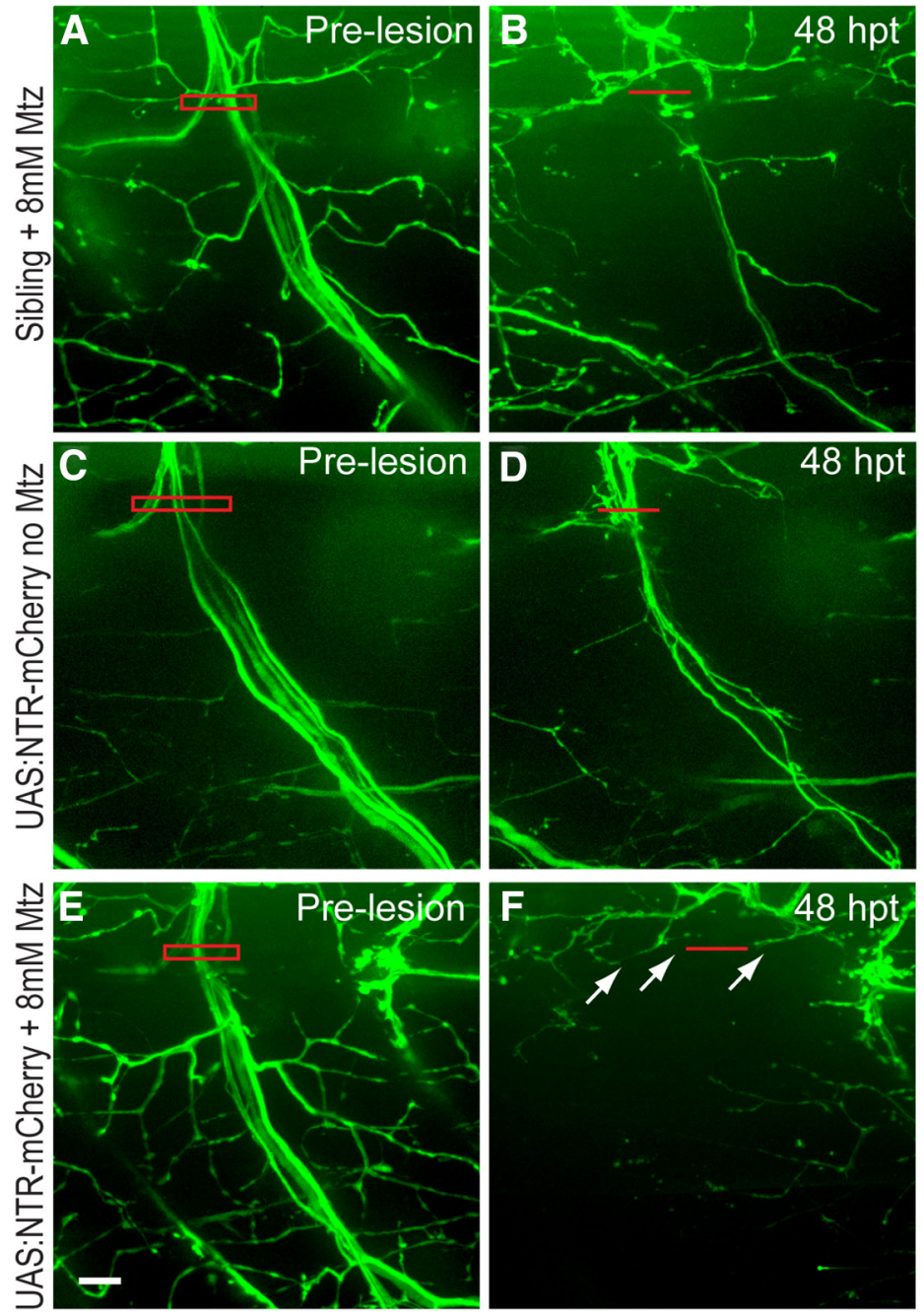

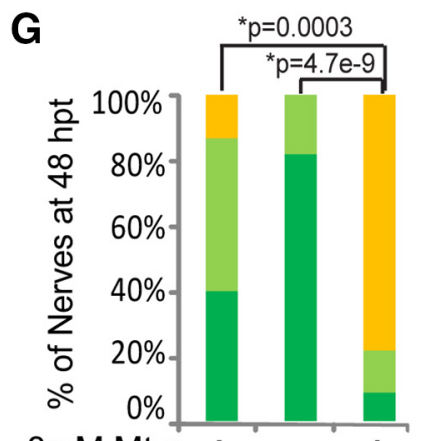

No/ Weak

Moderate

Strong
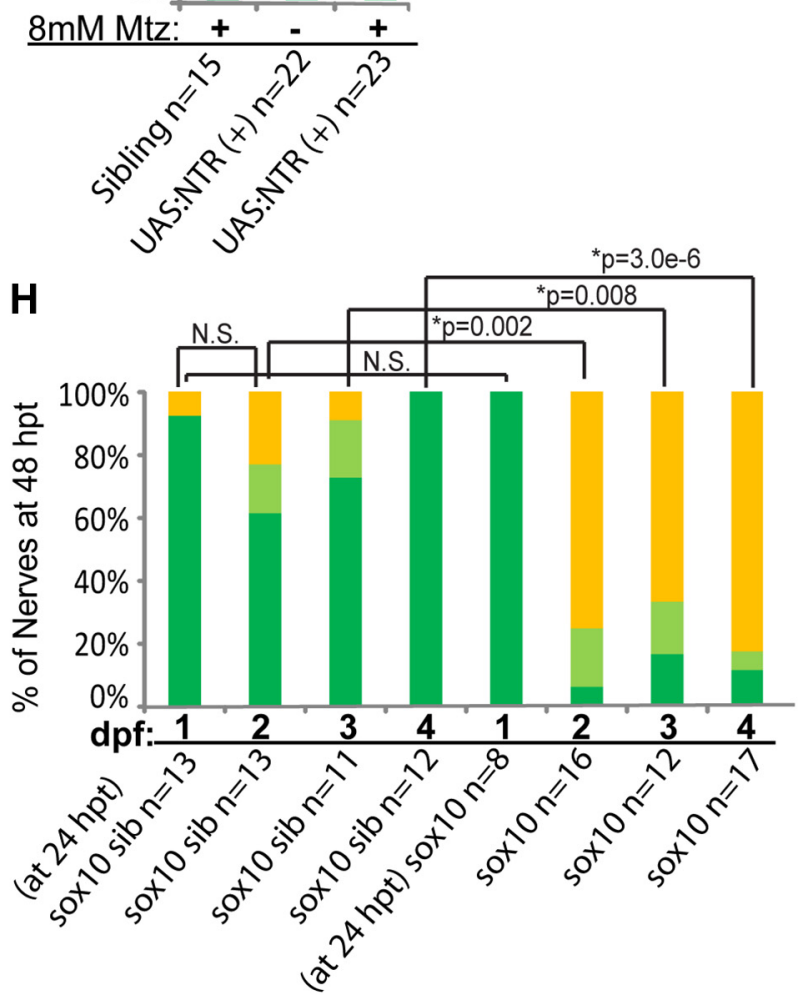

Figure 5. Schwann cells must be present during regeneration to direct axons. Axons regenerate normally in control wild-type larvae bathed in Mtz $(\boldsymbol{A}, \boldsymbol{B})$ and sox10:NTR-mCherry larvae not exposed to $\mathrm{Mtz}(\boldsymbol{C}, \boldsymbol{D})$. Axon regrowth is misguided after transection in sox10:NTR-mCherry larvae exposed to $8 \mathrm{~mm} \mathrm{Mtz}(\boldsymbol{E}, \boldsymbol{F})$. $\boldsymbol{G}, \boldsymbol{H}$, Quantification of the extent of nerve regrowth at $48 \mathrm{hpt}$ using categories established in Figure 1 of siblings and transgenic animals exposed to $\mathrm{Mtz}(\boldsymbol{G})$ and in siblings (sib) and sox $10^{-/-}$mutants with nerves transected at $1-4 \mathrm{dpf}(\boldsymbol{H})$.

outline a path toward their original targets (Cajal, 1928; Ide et al., 1983; Hall, 1986a; Chen et al., 2005; McDonald et al., 2006; Parrinello et al., 2010). Alternatively, denervated Schwann cells in the distal nerve stump might produce factors that direct regrowing axons onto the original path, but the identity of such factors has remained mostly elusive (Politis et al., 1982; Kuffler, 1986; Heumann et al., 1987). During development, when differentiated Schwann cells are absent, axons fasciculate with and grow along other axons (Tessier-Lavigne and Goodman, 1996; McDonald et al., 2006), suggesting that axons form a suitable substrate to support axonal growth. Furthermore, our live-cell imaging reveals that regenerating axons fasciculate with pioneering axons (Fig. $6 D-H)$.

To determine whether a physical scaffold delineating the original path is sufficient to guide motor axons, we generated two experimental paradigms that provide a permissive scaffold devoid of Schwann cells. First, we took advantage of a transgenic line we had generated previously, in which axonal fragmentation is delayed for $>1$ week as a result of overexpression of the Wallerian degeneration slow $\left(\mathrm{Wld}^{\mathrm{s}}\right)$ protein in motor neurons (Rosenberg et al., 2012). Therefore, we transected nerves in larvae lacking Schwann cells and expressing Wld s selectively in motor axons ( $\mathrm{Tg}\left(m n x 1: G F P\right.$; $\left.W l d^{s}-e G F P\right)$;sox $\left.10^{-/-}\right)$to generate an axonal scaffold distal to the transection gap completely lacking Schwann cells (Fig. 7). Consistent with previously published results (Lunn et al., 1989; Rosenberg et al., 2012), we find that, in the presence of Schwann cells, regenerating axons extended alongside and intermingled with Wld ${ }^{\mathrm{s}}$-positive axons, demonstrating that they are not inhibitory to axon regrowth (Fig. 7E$H)$. Despite the presence of an axonal scaffold positioned in close proximity to the proximal stump (Fig. $7 I-L$ ), in larvae lacking Schwann cells, regenerating axons still failed to navigate onto their original path and instead extended along ectopic trajectories identical to what we observed in sox $10^{-/-}$mutants (Fig. 7, compare $A-D, I-L$, quantified in $U$ ).

Crossing the transection gap is a well known challenge for regenerating peripheral axons (Zochodne, 2008), presenting one possible explanation why regenerating axons extended along ectopic trajectories despite the presence of an axonal scaffold along their original path. To test whether a permissive scaffold spanning the injury gap is sufficient for proper regenerative growth, we provided regenerating axons with a continuous axonal scaf- 

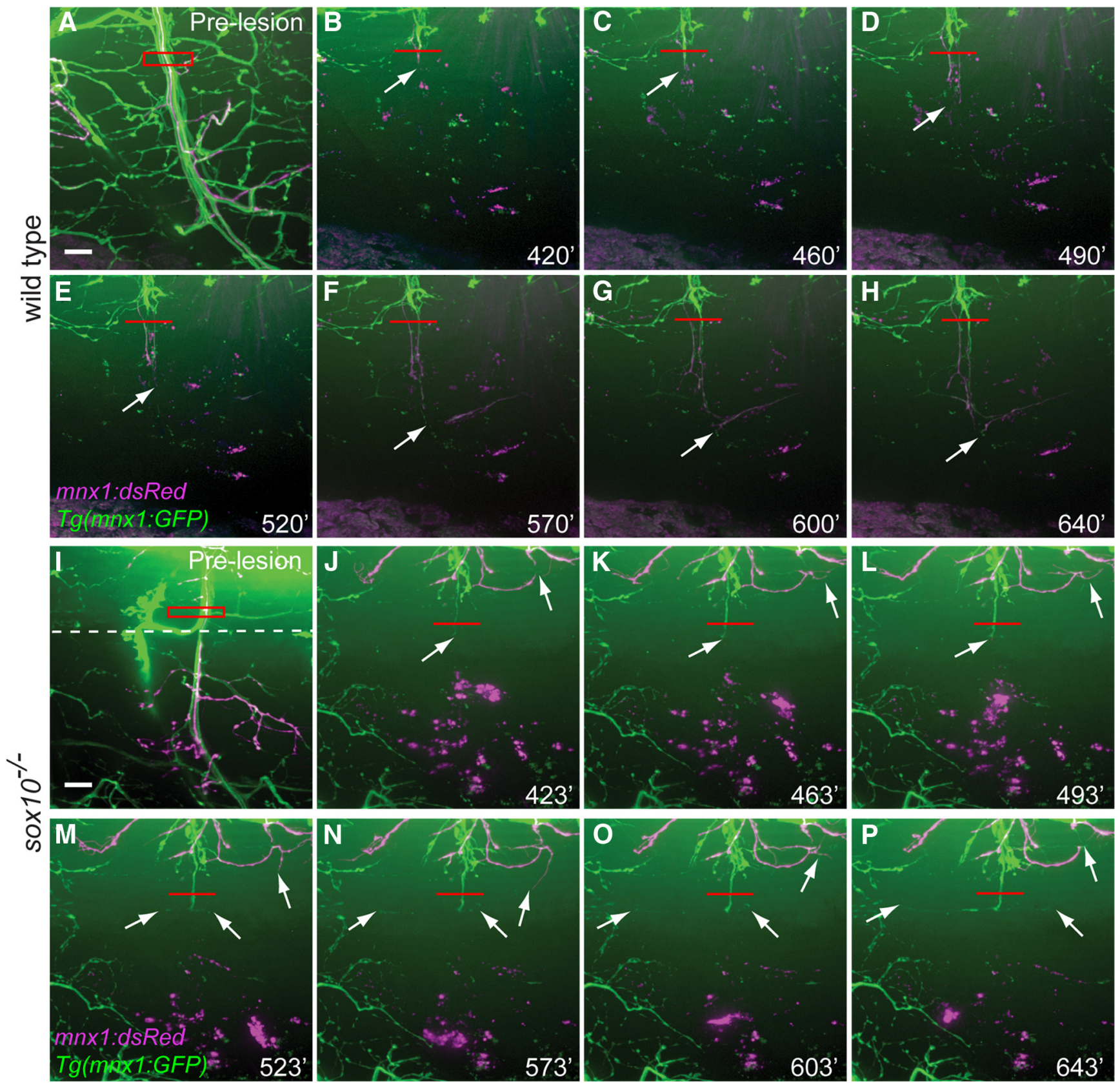

Figure 6. Schwann cells direct regrowing axons as they extend from the proximal stump. $\boldsymbol{A}-\boldsymbol{H}$, Nerve regeneration time course in wild-type $\operatorname{Tg}(m n x 1$ :GFP) nerves with stochastically singlelabeled axons. Axons extend across the lesion gap, into the ventral myotome, and fully traverse the original axonal path over several hours. I-P, Axons sprout and extend from the proximal stump

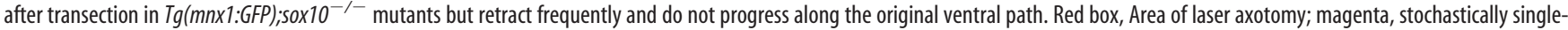
labeled axons (mnx1:DsRed); arrows, most ventral sprouts. Scale bar, $10 \mu \mathrm{m}$.

fold that spanned the injury gap and extended along the entirety of the original path. We generated this uninterrupted axonal scaffold devoid of Schwann cells by transecting approximately half of the 60-80 motor axons in the motor nerve (Fig. 7). In wild-type siblings, the vast majority of regrowing axons in partially transected nerves regrew along their original trajectory, with few axons straying from appropriate trajectories at $48 \mathrm{hpt}$ (Fig. $7 \mathrm{M}-\mathrm{P}$, quantified in $V$ ). In mutants lacking Schwann cells, we observed axons regenerating along ectopic trajectories in $\sim 50 \%$ of partially transected nerves ( $n=22$ of 44 ), down from $\sim 90 \%$ in fully transected nerves lacking Schwann cells (Fig. 7Q-T, quantified in $U, V)$. Thus, the presence of a continuous axonal scaffold that bridges the transection gap can only partially compensate for the role of Schwann cells in directing regrowing axons onto their original path. Combined, our data provide compelling evidence that, in vivo, Schwann cells serve regrowing axons with more than a permissive substrate that simply connects regenerating growth cones with the denervated Schwann cells along their original path. Instead, we propose that Schwann cells actively guide axons across the injury gap and toward their original path.

\section{The DCC guidance receptor is required for regenerative} axon guidance

We next sought to define the role of canonical axon guidance systems in Schwann cell-dependent guidance during regeneration. Several canonical axon guidance systems, including Netrin 

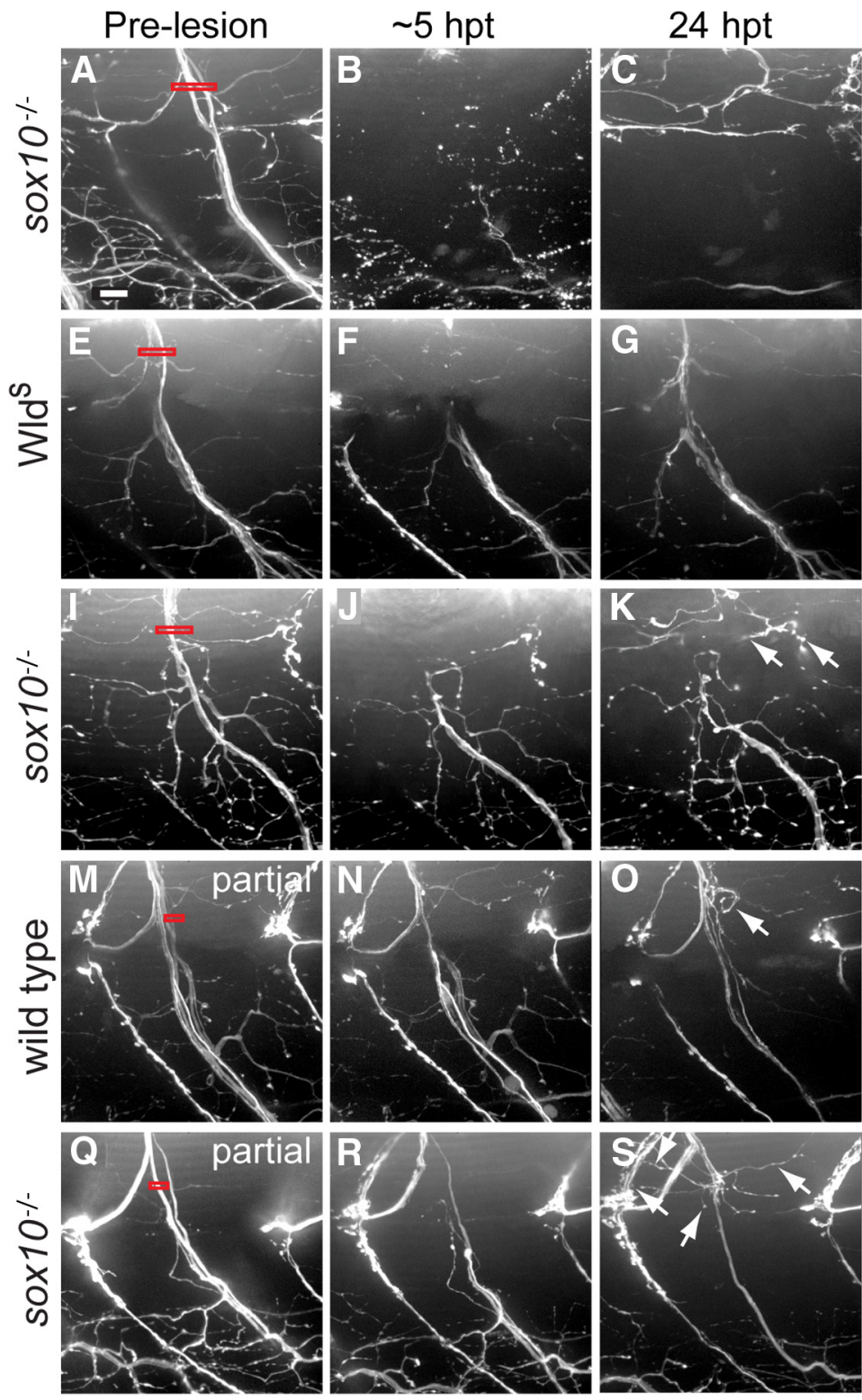
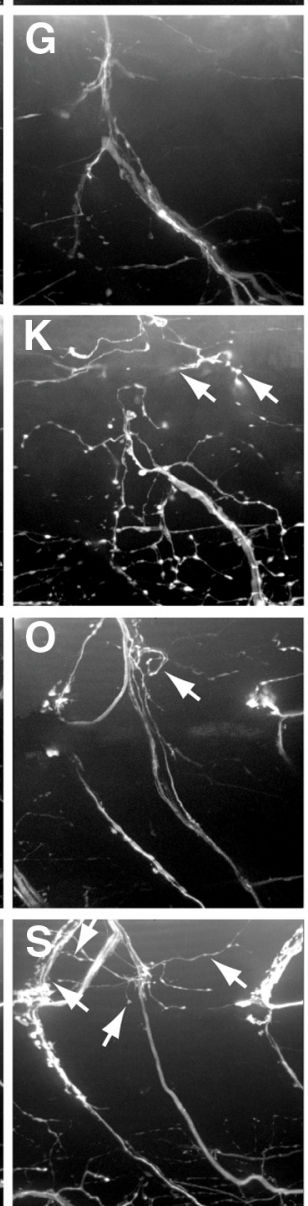
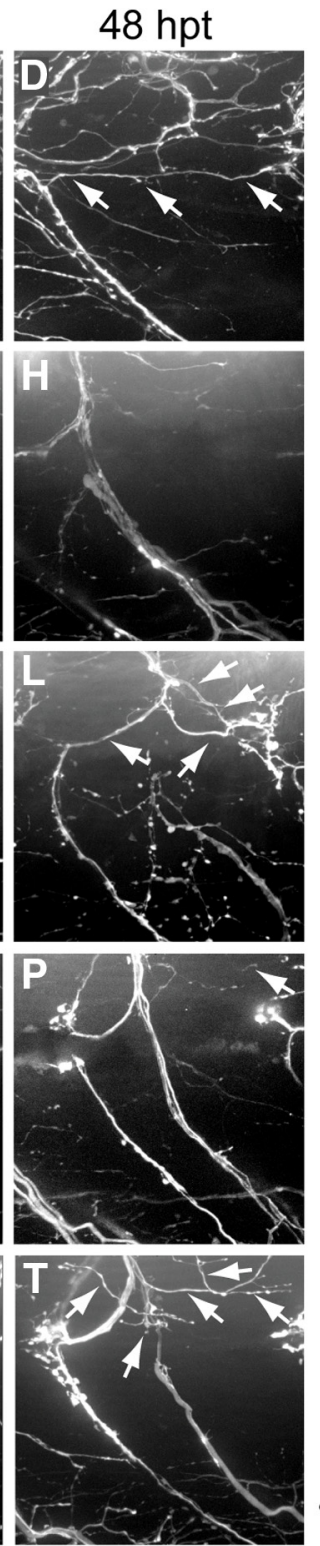

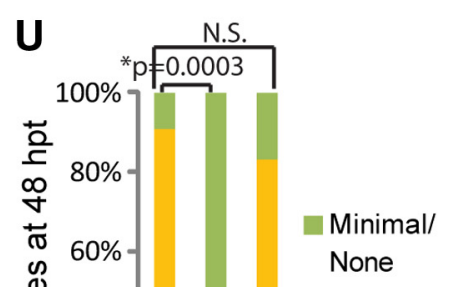

Misguided

Figure 7. A physical axonal scaffold fails to compensate for the absence of Schwann cells. Red box, Site of either full or partial nerve transection. A, Pre-lesion nerve in a Tg(mnx1:GFP);Sox 10-/mutant. $\boldsymbol{B}$, At $5 \mathrm{hpt}$. $\boldsymbol{C}, \boldsymbol{D}$, Regrowth is misguided after 24 and $48 \mathrm{hpt.} \boldsymbol{F}-\boldsymbol{H}, \boldsymbol{J}-\boldsymbol{L}$, Axonal tissue distal to nerve lesion is WId ${ }^{5}$ positive and will remain intact for 1 week after lesion. $\boldsymbol{E}$, Pre-lesion nerve in a $\operatorname{Tg}\left(m n \times 1: G F P ; m n x 1: W / d^{5}-e G F P\right) . \boldsymbol{F}$, At $5 \mathrm{hpt}$, distal nerve remains intact. $\mathbf{G}, \boldsymbol{H}$, Regrowing axons fasciculate and grow along WId ${ }^{5}$-positive distal nerve scaffold. $\boldsymbol{I}$, Pre-lesion nerve in a

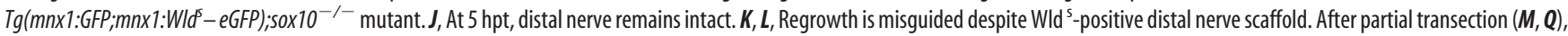
only axonal tissue distal to cut fascicles will fragment $(\boldsymbol{N}, \boldsymbol{R}) . \boldsymbol{O}, \boldsymbol{P}$, Regrowth in a wild-type sibling after 24 and $48 \mathrm{~h}$ after partial transection. $\mathbf{S}, \boldsymbol{I}$, Regrowth in sox $10^{-/-}$mutant after 24 and $48 \mathrm{~h}$ after partial transection is misguided despite intact axonal scaffold. Arrows, Misguided regrowth. Scale bar, $10 \mu \mathrm{m}$. $\boldsymbol{V}$, Quantification of misguidance in regenerated nerves $48 \mathrm{~h}$ after transection. $\boldsymbol{U}$, Quantification of misguidance in regenerated nerves $48 \mathrm{~h}$ after partial transection.

and its receptor DCC have been implicated in promoting the extent of axon regeneration (Madison et al., 2000; Tanno et al., 2005; Gabel et al., 2008; Webber et al., 2011). However, an in vivo function for DCC in regenerative axon guidance has not been defined. In situ hybridizations at $5 \mathrm{dpf}$ revealed that $d c c$ mRNA is expressed throughout the ventral spinal cord (Fig. 8A) and that dcc mRNA colocalizes with GFP-positive motor neurons in $\operatorname{Tg}(m n x 1: G F P)$ larvae, as well as with Schwann cells along the motor nerve in $\mathrm{Tg}(-7.2$ sox 10:Gal4VP16;UAS:GFP) larvae, similar to what has been reported in mouse (Fig. $8 B-D, G, H$; Webber et al., 2011). Netrin1a mRNA is ubiquitous throughout the periphery, both before and after transection (data not shown; Fig. $8 L$ ), whereas netrin $1 b$ mRNA is concentrated in the ventral spinal cord but also colocalizes with Schwann cells along the motor nerve before and after transection (data not shown; Fig. 8I-K). Importantly, dcc mRNA in GFP-positive motor neurons was detectable during the period of initial axonal regrowth at 6 and $9 \mathrm{hpt}$ (Fig. 8C-F; data not shown).

To test whether DCC is required for motor axon regeneration in vivo, we transected nerves in $d c c^{z m 130198}$ mutants. The $d c c^{z m 130198}$ allele carries a retroviral insertion 106 bp upstream of the start codon, resulting in a $90 \%$ reduction of $d c c$ mRNA (Jain et al., 2014). Importantly, motor axons and Schwann cells develop normally in $d c c^{z m 130198}$ mutants, and at $5 \mathrm{dpf}$, they are morphologically indistinguishable from those in wild-type siblings (Fig. 8N, R; data not shown). By $48 \mathrm{hpt}$, we found that $78 \%$ of transected $d c^{z m 130198}$ mutant nerves extended motor axons along their original path ( $n=46$ of 59 nerves), similar to what we 

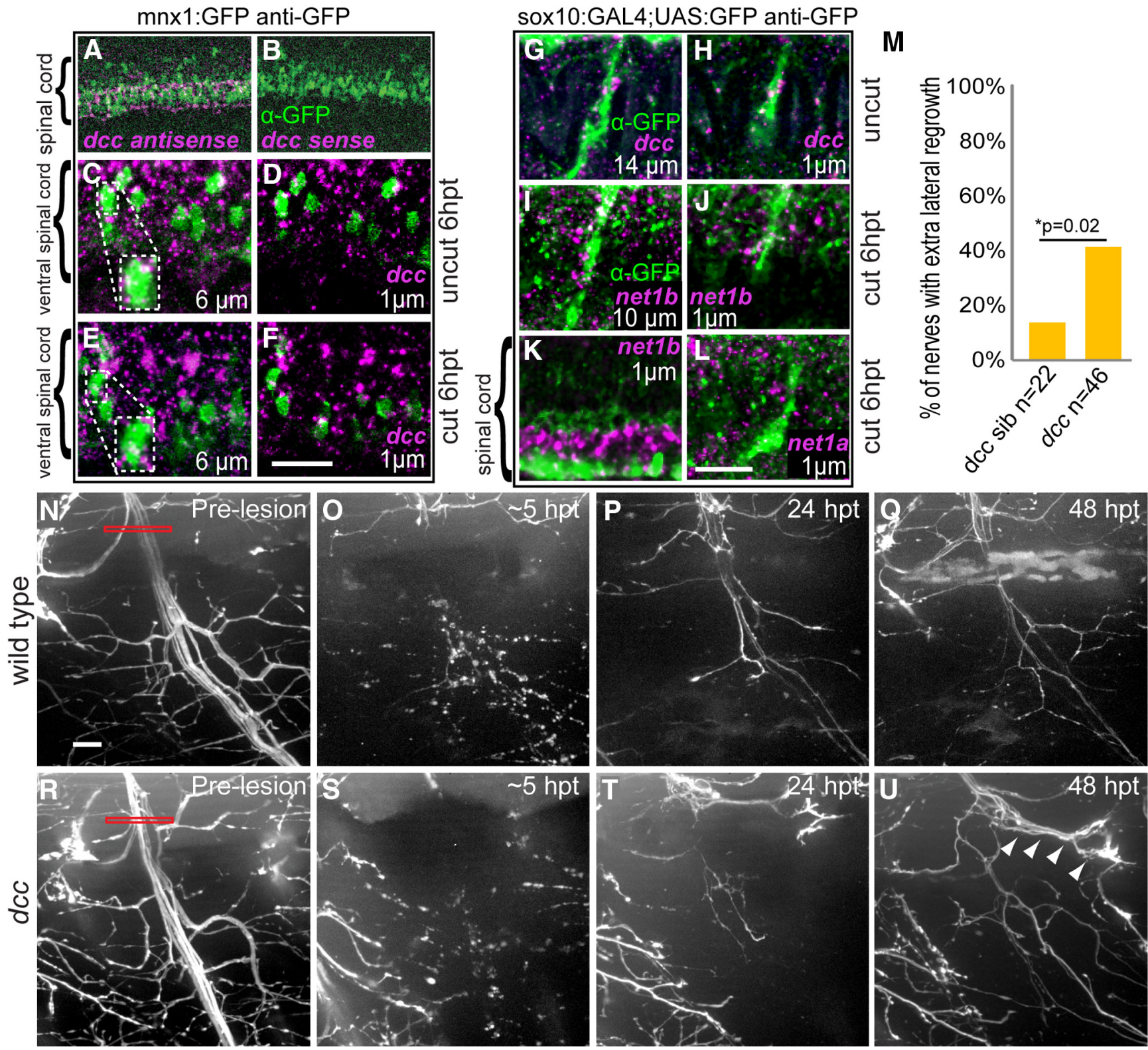

Figure 8. $\quad D C C$ directs axon regeneration. $\boldsymbol{A}-\boldsymbol{L}$, In situ hybridizations (ISH) (mRNA in magenta) in 5 dpf larvae with anti-GFP (green) antibody staining of motor neurons in $T g(m n x 1: G F P)$ ( $\boldsymbol{A}-\boldsymbol{F})$ or of Schwann cells in Tg(-7.2sox10:Gal/VVP16;UAS:GFP) (G-U). A-F, ISH for dcc with antibody staining of motor neurons. $\boldsymbol{A}, \boldsymbol{B}$, Twenty times magnification of 5 dpf spinal cord with dcc antisense and $d c c$ sense probes. $C-F$, dcc at $6 \mathrm{hpt}$ on cut and uncut hemisegments from the same animal in $6 \mu \mathrm{m} z$-stacks and $1 \mu \mathrm{m}$ single $z$-plane. $\mathbf{G}, \boldsymbol{H}$, ISH for dcc with antibody staining of Schwann cells in 14 $\mu \mathrm{m} z$-stacks and $1 \mu \mathrm{m}$ single $z$-plane. $\boldsymbol{I}, \boldsymbol{J}, \boldsymbol{K}$, ISH for net $1 b$ with antibody staining of Schwann cells in $10 \mu \mathrm{m} z$-stacks and $1 \mu \mathrm{m}$ single $z$-planes. L, ISH for net $1 a$ with antibody staining of Schwann cells in $1 \mu \mathrm{m}$ single z-plane. G-J, L, Spinal cord is just above frame of image. $\boldsymbol{M}$, Quantification of nerves with aberrant lateral regrowth. sib, Sibling. $\boldsymbol{N}$, Pre-lesion nerve in $T g(m n x 1: G F P)$ sibling, at

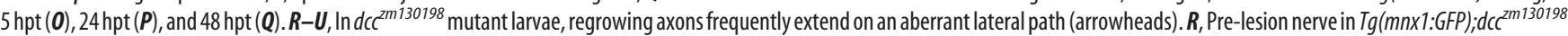
mutant at $5 \mathrm{hpt}(\boldsymbol{S})$. Although some axons regrow along their original trajectory, many axons grow incorrectly on a lateral path $(\boldsymbol{T}, \boldsymbol{U}$, arrowheads). Scale bar, $10 \mu \mathrm{m}$.

observed in wild-type siblings ( $90 \%, n=28$ of 31 nerves). However, in $\sim 40 \%$ of the transected nerves in $d_{c} c^{z m 130198}$, regenerating motor axons extended not only along their original path but also along ectopic lateral trajectories (Fig. $8 T, U$, quantified in $M$ ). Importantly, misdirected axons deviated from the original path at the level of the injury gap and extended into lateral territories, albeit less frequently, but similar to what we observed in mutants lacking Schwann cells (Fig. 3). Thus, dcc is required in vivo to guide regenerating motor axons across the injury gap toward their original trajectory. Combined, our results demonstrate that both Schwann cell- and $d c c$-dependent guidance is required during the early steps of axon regeneration to direct regenerating growth cones toward their original path.

\section{Discussion}

Axons in the peripheral nervous system can reestablish functional connections with their original synaptic targets, primarily because the PNS environment promotes regrowth (Aguayo et al., 1981; David and Aguayo, 1981). Thus, to understand how peripheral axons regenerate, it is fundamentally important to visualize how injured axons interact with their cellular environment in vivo. We previously developed a system to record the process of motor axon degeneration in vivo and to document the intricate cellular interactions between injured motor axons and macrophages (Rosenberg et al., 2012). Here, we use this system to examine how Schwann cells respond to nerve injury. We find that 
Schwann cells react to injury in synchrony with dynamic changes in axonal morphology, demonstrate that Schwann cells provide more than a simple permissive substrate to direct regenerating axons, and illustrate a role for $d c c$-dependent signaling in guiding sprouting growth cones across the injury gap and toward their original path.

\section{Changes in Schwann cell morphology and axonal fragmentation are highly synchronized}

Schwann cells are the principle glia of the peripheral nervous system and are known to promote axonal regeneration. After injury, Schwann cells collaborate with macrophages to degrade axon and myelin debris, clearing the path for axon regeneration. They also undergo dramatic morphological changes, reflecting their dedifferentiation to a more immature state, critical for their own proliferation and production of diffusible factors that promote axon outgrowth (Holtzman and Novikoff, 1965; Scherer and Easter, 1984; Jessen and Mirsky, 1999, 2008). However, whether axonal degeneration is synchronized with the various changes in Schwann cell behavior has not been examined in live intact animals. We find that, as axons fragment, distal Schwann cells change their morphology and over the next $24 \mathrm{~h}$ retain this rounder appearance (Fig. $1 C-H$ ). During the same time period, Schwann cells also become motile, extending toward and sometimes across the lesion site (Fig. 2). The functional significance of this early migration is unclear, because $\sim 80 \%$ of transected nerves regenerated, whereas Schwann cell migration was detectable in only $42 \%$ of these nerves.

Earlier work suggested that Schwann cell proliferation is important for nerve regeneration, but the time period during which proliferation is critical for regeneration has remained elusive (Hall, 1986a; Scaravilli et al., 1986). We find that, within the first $10-13 \mathrm{hpt}$, Schwann cell proliferation was only evident in $14 \%$ of transected nerves, consistent with the idea that Schwann cell proliferation is less important when axons cross the injury site and extend toward their original trajectory but might become important later to replace lost Schwann cells and remyelinate regrown axons. Finally, after axons crossed the injury gap and extended over the denervated Schwann cells along the original path, distal Schwann cell membranes began to revert to a smoother, pre-lesion appearance (Fig. $1 I-L$ ). Thus, after nerve injury, axon and Schwann cell behaviors change dramatically and with remarkable synchronicity.

\section{Schwann cells direct regenerating axons}

Peripheral axons often regenerate successfully after crush injuries, as the basal lamina remains essentially intact at the injury site and is continuous with the band of Bungner, which can serve as a substrate (Cajal, 1928; Scherer and Easter, 1984; Nguyen et al., 2002). In contrast, complete nerve transection disrupts Schwann cells and the basal lamina, resulting in a gap at the injury site. Although peripheral axons can regenerate across the transection gap, removal of the distal stump or increasing the size of the gap diminishes the ability of axons to regenerate, indicating that the distal nerve provides critical signals that support regeneration (Lundborg et al., 1981, 1982, 1986). One perspective that dominates the literature is that Schwann cells produce neurotrophic factors that promote axon regrowth (for review, see Vargas and Barres, 2007).

We assessed regeneration in four mutants that lack Schwann cells without affecting development or morphology of motor axons (Fig. 3) or Wallerian degeneration (Rosenberg et al., 2012). Our time-lapse movies demonstrate that, early in regeneration, growth cones sprout from sox $10^{-1-}$ nerve stumps with the same latency and extend at similar growth rates compared with wild type, but along ectopic routes ignoring their original trajectory (Fig. 6). Although we only analyzed axonal growth rates until 13 hpt, our data suggest that, early during the regeneration process, pioneering motor axons can rely on cell types other than Schwann cells as their source of growth-promoting factors. For example, neurotrophins are known to also be expressed by skeletal muscle (Griesbeck et al., 1995), and in denervated gastrocnemius muscle, BDNF mRNA levels increase (Funakoshi et al., 1993). At the same time, our results also provide compelling in vivo evidence that Schwann cells provide directionality to axons as they cross the injury site and navigate onto their original trajectory.

The prevailing view in the literature is that denervated Schwann cells themselves, or in conjunction with fibroblasts, form a bridge across the lesion site that provides regenerating axons with a permissive substrate that leads to the denervated Schwann cells in the distal nerve stump along the original trajectory (Cajal, 1928; Ide et al., 1983; Hall, 1986a,b; Chen et al., 2005; McDonald et al., 2006; Parrinello et al., 2010). Although even basal lamina extracted from peripheral nerve segments and then implanted as a scaffold at the proximal nerve is able to provide an effective pathway for regrowing axons (Ide et al., 1983), if and to which extent purely axonal scaffolds can serve as a regenerative substrate in vivo is unclear. We find that, in the presence of Schwann cells, a continuous physical bridge consisting of nontransected axons was permissive to regrowth. In the absence of Schwann cells, such axonal scaffolds improved directional regrowth by $50 \%$ compared with when no bridge was provided (Fig. 7Q-T, and $V$ compared with $A-D, U$ ) but failed to fully compensate for the absence of Schwann cells and resulted in twice the frequency of misguided axons $(\sim 50 \%)$ compared with partially transected wild-type nerves ( $\sim 20 \%$; Fig. $7 M-P, U)$. Thus, in vivo, permissive Schwann cell free substrates support partial axonal regeneration yet fail to compensate for the robust guidance provided by Schwann cells. Importantly, our experiments do not distinguish between a contact-dependent role for Schwann cells in directing regenerating axons, e.g., by providing a permissive substrate unique to Schwann cells, and a contact independent role for Schwann cells, e.g., in providing directional guidance cues emanating from Schwann cells distal to the lesion site.

\section{DCC directs axons early during regeneration}

Complete nerve transection resulting in an injury gap resembles development, when pioneering axons navigate through a changing environment. Expression of the canonical guidance molecules Netrin 1 and Slit2 are upregulated in the distal nerve stump after transection (Wang et al., 1999; Madison et al., 2000; Tanno et al., 2005; Park et al., 2007), as are NGF and GDNF, which can act as neurotropic cues (Cajal, 1928; Letourneau, 1978; Gundersen and Barrett, 1979; Schuster et al. 2010; Arthur-Farraj et al., 2012). During development, DCC is expressed on axonal growth cones and responds to Netrin secreted from midline glia cells (Kennedy et al., 1994; Chan et al., 1996; Kolodziej et al., 1996; Mitchell et al., 1996; Lauderdale et al., 1998). After sciatic nerve transection, netrin-1 mRNA levels are upregulated in the band of Bungner Schwann cells (Madison et al., 2000). After peripheral nerve transection in mammals, regenerating axons and Schwann cells express DCC (Madison et al., 2000; Webber et al., 2011). Furthermore, siRNA knockdown of $d c c$ reduces the number and extent of regenerating axon fibers (Webber et al., 2011), and in netrin-1 heterozygous mice, the extent of peripheral nerve regeneration is significantly reduced (Jaminet et al., 2013). However, if and to what extent Netrin/DCC signaling guides regenerating axons has not been examined in vivo. 
Although we were not able to resolve differences in mRNA expression before and in the hours after nerve transection, we find that the components of this signaling system are present in the cells important for axon regeneration. Consistent with a potential role in motor axon regeneration, we find that netrin $1 b$ mRNA colocalizes with Schwann cells, and that besides the widespread distribution of $d c c$ mRNA in the spinal cord, $d c c$ also localizes to motor neurons and Schwann cells (Fig. 8). We find that motor axons in $d c c^{z m 130198}$ mutants regenerate, yet a significant portion of motor axons extended along ectopic trajectories, somewhat similar to what we observed in animals lacking Schwann cells. Future experiments will determine whether in zebrafish $d c c$ function is required in regenerating motor axons to respond to Netrin, possibly secreted from distal denervated Schwann cells, to attract axons across the injury site. Alternatively, $d c c$ might function in proximal nerve stump Schwann cells, drawing these Schwann cells across the injury site, thereby forming a physical bridge that regenerating axons use to cross the injury gap. Our combined results reveal a novel and definitive role for Schwann cells and $d c c$-mediated guidance early in peripheral nerve regeneration to direct growth cones across the transection gap and onto their original axonal trajectory.

\section{Notes}

Supplemental material for this article is available at http://www.med. upenn.edu/granato/publications.shtml. Movie 1, Axonal and Schwann cell behaviors after nerve transection. Movie 2, Schwann cell migration after nerve transection. Movie 3, Axonal regeneration in wild type. Movie 4 , Axonal regeneration in sox $10^{-1-}$ mutants lacking Schwann cells. This material has not been peer reviewed.

\section{References}

Abernethy DA, Thomas PK, Rud A, King RH (1994) Mutual attraction between emigrant cells from transected denervated nerve. J Anat 184:239249. Medline

Aguayo AJ, David S, Bray GM (1981) Influences of the glial environment on the elongation of axons after injury: transplantation studies in adult rodents. J Exp Biol 95:231-240. Medline

Arthur-Farraj PJ, Latouche M, Wilton DK, Quintes S, Chabrol E, Banerjee A, Woodhoo A, Jenkins B, Rahman M, Turmaine M, Wicher GK, Mitter R, Greensmith L, Behrens A, Raivich G, Mirsky R, Jessen KR (2012) c-Jun reprograms Schwann cells of injured nerves to generate a repair cell essential for regeneration. Neuron 75:633-647. CrossRef Medline

Asakawa K, Suster ML, Mizusawa K, Nagayoshi S, Kotani T, Urasaki A, Kishimoto Y, Hibi M, Kawakami K (2008) Genetic dissection of neural circuits by Tol 2 transposon-mediated Gal4 gene and enhancer trapping in zebrafish. Proc Natl Acad Sci U S A 105:1255-1260. CrossRef Medline

Beuche W, Friede RL (1984) The role of non-resident cells in Wallerian degeneration. J Neurocytol 13:767-796. CrossRef Medline

Brosius Lutz A, Barres BA (2014) Contrasting the glial response to axon injury in the central and peripheral nervous systems. Dev Cell 28:7-17. CrossRef Medline

Brushart TM (2011) Nerve repair. New York: Oxford UP.

Bungner OV (1891) Uber die Degenerierungs- und Regenerierungsvorgange an Nerven mit Verleztungen. Beitr Pathol Anat 10:321-387.

Cajal R (1928) Degeneration and regeneration of the nervous system. Oxford, UK: Oxford UP.

Chan SSYS, Zheng H, Su MWW, Wilk R, Killeen MTT, Hedgecock EMM, Culotti JGG (1996) UNC-40, a C. elegans homolog of DCC (Deleted in Colorectal Cancer), is required in motile cells responding to UNC-6 netrin cues. Cell 87:187-195. CrossRef Medline

Chen YY, McDonald D, Cheng C, Magnowski B, Durand J, Zochodne DW (2005) Axon and Schwann cell partnership during nerve regrowth. J Neuropathol Exp Neurol 64:613-622. CrossRef Medline

Chen ZL, Yu WM, Strickland S (2007) Peripheral regeneration. Annu Rev Neurosci 30:209-233. CrossRef Medline

Curado S, Anderson RM, Jungblut B, Mumm J, Schroeter E, Stainier DY (2007) Conditional targeted cell ablation in zebrafish: a new tool for regeneration studies. Dev Dyn 236:1025-1035. CrossRef Medline
David S, Aguayo AJ (1981) Axonal elongation into peripheral nervous system "bridges" after central nervous system injury in adult rats. Science 214:931-933. CrossRef Medline

Dutton KA, Pauliny A, Lopes SS, Elworthy S, Carney TJ, Rauch J, Geisler R, Haffter P, Kelsh RN (2001) Zebrafish colourless encodes sox10 and specifies non-ectomesenchymal neural crest fates. Development 128: 4113-4125. Medline

Flanagan-Steet H, Fox MA, Meyer D, Sanes JR (2005) Neuromuscular synapses can form in vivo by incorporation of initially aneural postsynaptic specializations. Development 132:4471-4481. CrossRef Medline

Funakoshi H, Frisén J, Barbany G, Timmusk T, Zachrisson O, Verge VM, Persson H (1993) Differential expression of mRNAs for neurotrophins and their receptors after axotomy of the sciatic nerve. J Cell Biol 123:455465. CrossRef Medline

Gabel CV, Antoine F, Antonie F, Chuang CF, Samuel ADT, Chang C (2008) Distinct cellular and molecular mechanisms mediate initial axon development and adult-stage axon regeneration in C. elegans. Development 135:1129-1136. CrossRef Medline

Garbay B, Heape AM, Sargueil F, Cassagne C (2000) Myelin synthesis in the peripheral nervous system. Prog Neurobiol 61:267-304. CrossRef Medline

Griesbeck O, Parsadanian AS, Sendtner M, Thoenen H (1995) Expression of neurotrophins in skeletal muscle: quantitative comparison and significance for motoneuron survival and maintenance of function. J Neurosci Res 42:21-33. CrossRef Medline

Gundersen RW, Barrett JN (1979) Neuronal chemotaxis: chick dorsal-root axons turn toward high concentrations of nerve growth factor. Science 206:1079-1080. CrossRef Medline

Hahn AF, Chang Y, Webster HD (1987) Development of myelinated nerve fibers in the sixth cranial nerve of the rat: a quantitative electron microscope study. J Comp Neurol 260:491-500. CrossRef Medline

Hall SM (1986a) The effect of inhibiting Schwann cell mitosis on the reinnervation of acellular autografts in the peripheral nervous system of the mouse. Neuropathol Appl Neurobiol 12:401-414. CrossRef Medline

Hall SM (1986b) Regeneration in cellular and acellular autografts in the peripheral nervous system. Neuropathol Appl Neurobiol 12:27-46. CrossRef Medline

Heumann R, Korsching S, Bandtlow C, Thoenen H (1987) Changes of nerve growth factor synthesis in nonneuronal cells in response to sciatic nerve transection. J Cell Biol 104:1623-1631. CrossRef Medline

Holtzman E, Novikoff AB (1965) Lysomes in the rat sciatic nerve following crush. J Cell Biol 27:651-669. CrossRef Medline

Ide C (1996) Peripheral nerve regeneration. Neurosci Res 25:101-121. CrossRef Medline

Ide C, Tohyama K, Yokota R, Nitatori T, Onodera S (1983) Schwann cell basal lamina and nerve regeneration. Brain Res 288:61-75. CrossRef Medline

Jain RA, Bell H, Lim A, Chien CB, Granato M (2014) Mirror movement-like defects in startle behavior of zebrafish dcc mutants are caused by aberrant midline guidance of identified descending hindbrain neurons. J Neurosci 34:2898-2909. CrossRef Medline

Jaminet P, Köhler D, Schäufele M, Rahmanian-Schwarz A, Lotter O, Fornaro M, Ronchi G, Geuna S, Rosenberger P, Schaller HE (2013) Evaluating the role of Netrin-1 during the early phase of peripheral nerve regeneration using the mouse median nerve model. Restor Neurol Neurosci 31: 337-345. CrossRef Medline

Jao LE, Maddison L, Chen W, Burgess SM (2008) Using retroviruses as a mutagenesis tool to explore the zebrafish genome. Brief Funct Genomic Proteomic 7:427-443. CrossRef Medline

Jessen KR, Mirsky R (1999) Why do Schwann cells survive in the absence of axons? Ann N Y Acad Sci 883:109-115. CrossRef Medline

Jessen KR, Mirsky R (2008) Negative regulation of myelination: relevance for development, injury, and demyelinating disease. Glia 56:1552-1565. CrossRef Medline

Kelsh RN, Brand M, Jiang YJ, Heisenberg CP, Lin S, Haffter P, Odenthal J, Mullins MC, van Eeden FJ, Furutani-Seiki M, Granato M, Hammerschmidt M, Kane DA, Warga RM, Beuchle D, Vogelsang L, NüssleinVolhard C (1996) Zebrafish pigmentation mutations and the processes of neural crest development. Development 123:369-389. Medline

Kennedy TE, Serafini T, de la Torre JR, Tessier-Lavigne M (1994) Netrins are diffusible chemotropic factors for commissural axons in the embryonic spinal cord. Cell 78:425-435. CrossRef Medline

Kolodziej PA, Timpe LC, Mitchell KJ, Fried SR, Goodman CS, Jan LY, Jan YN 
(1996) frazzled encodes a Drosophila member of the DCC immunoglobulin subfamily and is required for CNS and motor axon guidance. Cell 87:197-204. CrossRef Medline

Kucenas S, Takada N, Park HC, Woodruff E, Broadie K, Appel B (2008) CNS-derived glia ensheath peripheral nerves and mediate motor root development. Nat Neurosci 11:143-151. CrossRef Medline

Kuffler DP (1986) Isolated satellite cells of a peripheral nerve direct the growth of regenerating frog axons. J Comp Neurol 249:57-64. CrossRef Medline

Lakhina V, Marcaccio CL, Shao X, Lush ME, Jain RA, Fujimoto E, Bonkowsky JL, Granato M, Raper JA (2012) Netrin/DCC signaling guides olfactory sensory axons to their correct location in the olfactory bulb. J Neurosci 32:4440-4456. CrossRef Medline

Lauderdale JD, Pasquali SK, Fazel R, van Eeden FJ, Schauerte HE, Haffter P, Kuwada JY (1998) Regulation of netrin-la expression by hedgehog proteins. Mol Cell Neurosci 11:194-205. CrossRef Medline

Letourneau PC (1978) Chemotactic response of nerve fiber elongation to nerve growth factor. Dev Biol 66:183-196. CrossRef Medline

Lundborg G, Dahlin LB, Danielsen NP, Hansson HA, Larsson K (1981) Reorganization and orientation of regenerating nerve fibres, perineurium, and epineurium in preformed mesothelial tubes — an experimental study on the sciatic nerve of rats. J Neurosci Res 6:265-281. CrossRef Medline

Lundborg G, Longo FM, Varon S (1982) Nerve regeneration model and trophic factors in vivo. Brain Res 232:157-161. CrossRef Medline

Lundborg G, Dahlin LB, Danielsen N, Nachemson AK (1986) Tissue specificity in nerve regeneration. Scand J Plast Reconstr Surg 20:279-283. CrossRef Medline

Lunn ER, Perry VH, Brown MC, Rosen H, Gordon S (1989) Absence of Wallerian degeneration does not hinder regeneration in peripheral nerve. Eur J Neurosci 1:27-33. CrossRef Medline

Lyons DA, Pogoda HM, Voas MG, Woods IG, Diamond B, Nix R, Arana N, Jacobs J, Talbot WS (2005) Erbb3 and Erbb2 are essential for Schwann cell migration and myelination in zebrafish. Curr Biol 15:513-524. CrossRef Medline

Madison RD, Zomorodi A, Robinson GA (2000) Netrin-1 and peripheral nerve regeneration in the adult rat. Exp Neurol 161:563-570. CrossRef Medline

Martini R, Schachner M, Faissner A (1990) Enhanced expression of the extracellular matrix molecule J1/tenascin in the regenerating adult mouse sciatic nerve. J Neurocytol 19:601-616. CrossRef Medline

McDonald D, Cheng C, Chen Y, Zochodne D (2006) Early events of peripheral nerve regeneration. Neuron Glia Biol 2:139-147. CrossRef Medline

Mitchell KJ, Doyle JL, Serafini T, Kennedy TE, Tessier-Lavigne M, Goodman CS, Dickson BJ (1996) Genetic analysis of Netrin genes in Drosophila: Netrins guide CNS commissural axons and peripheral motor axons. Neuron 17:203-215. CrossRef Medline

Mullins MC, Hammerschmidt M, Haffter P, Nüsslein-Volhard C (1994) Large-scale mutagenesis in the zebrafish: in search of genes controlling development in a vertebrate. Curr Biol 4:189-202. CrossRef Medline

Myers PZ (1985) Spinal motoneurons of the larval zebrafish. J Comp Neurol 236:555-561. CrossRef Medline

Myers PZ, Eisen JS, Westerfield M (1986) Development and axonal outgrowth of identified motoneurons in the zebrafish. J Neurosci 6:22782289. Medline

Nguyen QT, Sanes JR, Lichtman JW (2002) Pre-existing pathways promote precise projection patterns. Nat Neurosci 5:861-867. CrossRef Medline

Park JI, Seo IA, Lee HK, Park HT, Shin SW, Park YM, Ahn KJ (2007) Netrin inhibits regenerative axon growth of adult dorsal root ganglion neurons in vitro. J Korean Med Sci 22:641-645. CrossRef Medline

Parrinello S, Napoli I, Ribeiro S, Digby PW, Fedorova M, Parkinson DB, Doddrell RDS, Nakayama M, Adams RH, Lloyd AC, Wingfield Digby P, Fedorova M, Parkinson DB, Doddrell RDS, Nakayama M, Adams RH, Lloyd AC (2010) EphB signaling directs peripheral nerve regeneration through Sox2dependent Schwann cell sorting. Cell 143:145-155. CrossRef Medline

Parsons MJ, Pisharath H, Yusuff S, Moore JC, Siekmann AF, Lawson N, Leach SD (2009) Notch-responsive cells initiate the secondary transition in larval zebrafish pancreas. Mech Dev 126:898-912. CrossRef Medline

Peri F, Nüsslein-Volhard C (2008) Live imaging of neuronal degradation by microglia reveals a role for v0-ATPase al in phagosomal fusion in vivo. Cell 133:916-927. CrossRef Medline

Perlin JR, Lush ME, Stephens WZ, Piotrowski T, Talbot WS (2011) Neuronal Neuregulin 1 type III directs Schwann cell migration. Development 138:4639-4648. CrossRef Medline
Perry VH, Brown MC (1992) Macrophages and nerve regeneration. Curr Opin Neurobiol 2:679-682. CrossRef Medline

Perry VH, Brown MC, Gordon S (1987) The macrophage response to central and peripheral nerve injury. A possible role for macrophages in regeneration. J Exp Med 165:1218-1223. CrossRef Medline

Peters A, Muir AR (1959) The relationship between axons and Schwann cells during development of peripheral nerves in the rat. Q J Exp Physiol Cogn Med Sci 44:117-130. Medline

Politis MJ, Ederle K, Spencer PS (1982) Tropism in nerve regeneration in vivo. Attraction of regenerating axons by diffusible factors derived from cells in distal nerve stumps of transected peripheral nerves. Brain Res 253:1-12. CrossRef Medline

Prendergast A, Linbo TH, Swarts T, Ungos JM, McGraw HF, Krispin S, Weinstein BM, Raible DW (2012) The metalloproteinase inhibitor Reck is essential for zebrafish DRG development. Development 139:1141-1152. CrossRef Medline

Rosenberg AF, Wolman MA, Franzini-Armstrong C, Granato M (2012) In vivo nerve-macrophage interactions following peripheral nerve injury. J Neurosci 32:3898 -3909. CrossRef Medline

ScaravilliF, LoveS, Myers R (1986) X-irradiation impairs regeneration of peripheral nerve across a gap. J Neurocytol 15:439-449. CrossRef Medline

Scherer SS, Easter SS Jr (1984) Degenerative and regenerative changes in the trochlear nerve of goldfish. J Neurocytol 13:519-565. CrossRef Medline

Schlaepfer WW, Myers FK (1973) Relationship of myelin internode elongation and growth in the rat sural nerve. J Comp Neurol 147:255-266. CrossRef Medline

Schröder JM, May R, Weis J (1993) Perineurial cells are the first to traverse gaps of peripheral nerves in silicone tubes. Clin Neurol Neurosurg [Suppl] 95:S78-S83. Medline

Schuster K, Dambly-Chaudière C, Ghysen A (2010) Glial cell line-derived neurotrophic factor defines the path of developing and regenerating axons in the lateral line system of zebrafish. Proc Natl Acad Sci U S A 107: 19531-19536. CrossRef Medline

Stoll G, Griffin JW, Li CY, Trapp BD (1989) Wallerian degeneration in the peripheral nervous system: participation of both Schwann cells and macrophages in myelin degradation. J Neurocytol 18:671-683. CrossRef Medline

Tanno T, Fujiwara A, Takenaka S, Kuwamura M, Tsuyama S (2005) Expression of a chemorepellent factor, Slit2, in peripheral nerve regeneration. Biosci Biotechnol Biochem 69:2431-2434. CrossRef Medline

Tessier-Lavigne M, Goodman CS (1996) The molecular biology of axon guidance. Science 274:1123-1133. CrossRef Medline

Thermes V, Grabher C, Ristoratore F, Bourrat F, Choulika A, Wittbrodt J, Joly JS (2002) I-SceI meganuclease mediates highly efficient transgenesis in fish. Mech Dev 118:91-98. CrossRef Medline

Vargas ME, Barres BA (2007) Why is Wallerian degeneration in the CNS so slow? Annu Rev Neurosci 30:153-179. CrossRef Medline

Villegas R, Martin SM, O’Donnell KC, Carrillo SA, Sagasti A, Allende ML (2012) Dynamics of degeneration and regeneration in developing zebrafish peripheral axons reveals a requirement for extrinsic cell types. Neural Dev 7:19. CrossRef Medline

Wang KH, Brose K, Arnott D, Kidd T, Goodman CS, Henzel W, TessierLavigne M (1999) Biochemical purification of a mammalian slit protein as a positive regulator of sensory axon elongation and branching. Cell 96:771-784. CrossRef Medline

Webber CA, Christie KJ, Cheng CHU, Martinez JA, Singh B, Singh D, Thomas D, Zochodne DW, Singh V (2011) Schwann cells direct peripheral nerve regeneration through the Netrin-1 receptors, DCC and Unc5H2. Glia 59:1503-1517. CrossRef Medline

Weis J, May R, Schröder JM (1994) Fine structural and immunohistochemical identification of perineurial cells connecting proximal and distal stumps of transected peripheral nerves at early stages of regeneration in silicone tubes. Acta Neuropathol 88:159-165. CrossRef Medline

Westerfield M, McMurray JV, Eisen JS (1986) Identified motoneurons and their innervation of axial muscles in the zebrafish. J Neurosci 6:22672277. Medline

Zhang J, Lefebvre JL, Zhao S, Granato M (2004) Zebrafish unplugged reveals a role for muscle-specific kinase homologs in axonal pathway choice. Nat Neurosci 7:1303-1309. CrossRef Medline

Zochodne DW (2008) Neurobiology of peripheral nerve regeneration. New York: Cambridge UP.

Zochodne DW (2012) The challenges and beauty of peripheral nerve regrowth. J Peripher Nerv Syst 17:1-18. CrossRef Medline 